\title{
Unsettling Settlements: Should Stipulated Reversals Be Allow ed te Trump Judgments' Collateral Estoppel Effects Under Neary?
}

\author{
Steven R. Harmon $\dagger$
}

Stipulated reversal is a procedure whereby litigants, typically during the pendency of an appeal and in order to facilitate settlement, ask the appellate court to dispose of the case by reversing the trial court's judgment rather than dismissing the appeal. In Neary v. Regents of University of California, the California Supreme Court broadly endorsed this procedure by holding that appeals courts should grant stipulated reversal requests absent extraordinary circumstances such as a compelling public interest.

Neary has been widely criticized, particularly insofar as stipulated reversal negates the issue preclusive effect of a trial court judgment so reversed. Under current collateral estoppel doctrine, a party found liable, for example, for manufacturing a defective product in an initial action is precluded from contesting the issue of defectiveness in later actions brought by different plaintiffs. However, if the initial action is reversed by stipulation, the first judgment has no preclusive effect in later actions.

This Comment examines the relationship between stipulated reversal under Neary and the preclusive effects of judgments. The author concludes that, notwithstanding the Neary presumption in favor of stipulated reversal, a judgment's collateral estoppel effects provide a sufficiently compelling public interest to support an appellate court's decision to deny a request for stipulated reversal. In particular, the

Copyright $\odot 1997$ California Law Review, Inc.

$\dagger$ A.B. 1994, Stanford University; J.D. candidate 1997, Boalt Hall School of Law, University of California, Berkeley. I wish to thank Professor Stephen Bamett for his advice, insights, and criticism. In addition, special thanks to the skilled editors and staff of the California Law Review. Any remaining mistakes or omissions are my own. I owe my deepest gratitude to my girlfriend and best friend, Elaine Brink, my parents, Bob and Sherry Harmon, and my grandparents; this Comment is dedicated to you in thanks for your love, support, generosity, and prayers. 
author argues that preserving a judgment's preclusive effects: 1) promotes judicial economy by encouraging settlement and avoiding repetitious litigation of identical issues; 2) prevents inconsistent judgments which undermine the integrity of the judicial system; and 3) avoids the appearance of manipulation of the judicial system by wealthy litigants, who can use stipulated reversal to "purchase" additional chances to relitigate issues already decided against them.

\section{INTRODUCTION}

In recent years, federal and state courts and legal commentators have hotly debated the propriety of judicial accommodation of parties' desires to nullify lower court judgments as part of settlement on appeal. ${ }^{1}$ Under a procedure known as "vacatur" or "stipulated reversal," the appellate court, after the trial court renders judgment and the losing party appeals, vacates or reverses the judgment below in response to a joint request by the parties presented as one of the conditions to a settlement agreement. Defenders of this practice have argued that it encourages settlement, relieves congested court dockets, and maintains the primacy of dispute resolution as a judicial function. ${ }^{2}$ Meanwhile, critics have assailed the procedure as undermining the integrity of the judicial process, converting judgments (and their precedential and preclusive effects) into bargaining chips, and allowing parties to sacrifice unrepresented public and private interests for their own. ${ }^{3}$

In California, supporters of stipulated reversal gained the upper hand with the California Supreme Court's decision in the 1992 case Neary v. Regents of the University of California. ${ }^{4}$ In Neary, the court held that, absent "extraordinary circumstances," courts of appeal should grant parties' requests to reverse trial court judgments, in order

1. See, e.g., U.S. Bancorp Mortgage Co. v. Bonner Mall Partnership, 115 S. Ct. 386 (1994) (establishing that, in federal court, mootness of a case's merits by reason of settlement does not justify vacatur of a judgment under review absent "exceptional circumstances"); National Union Fire Ins. Co. v. Seafirst Corp., 891 F.2d 762 (9th Cir. 1989) (reaffirming case-by-case framework for evaluation of settlement vacatur requests); In re Memorial Hosp., 862 F.2d 1299 (7th Cir. 1988) (rejecting vacatur); Nestle Co. v. Chester's Mkt., Inc., 756 F.2d 280 (2d Cir. 1985) (holding settling party entitled to vacatur of adverse trial judgment); Neary v. Regents of Univ. of Cal., 834 P.2d 119 (Cal. 1992) (embracing presumption in favor of granting stipulated reversal); Stephen R. Barnett, Making Decisions Disappear: Depublication and Stipulated Reversal in the California Supreme Cotrt, 26 LOY. L.A. L. REv. 1033 (1993) (criticizing stipulated reversal and Neary); Jill E. Fisch, Rewriting History: The Propriety of Eradicating Prior Decisional Law Through Settlement and Vacatur, 76 CORNELl L. REv. 589 (1991) (arguing that settlement vacatur distorts settlement and perverts the judicial process); Henry E. Klingeman, Note, Settlement Pending Appeal: An Argument for Vacatur, 58 FORDHAM L. REv. 233 (1989) (supporting settlement vacatur).

2. See, e.g., Neary, 834 P.2d at 121-24; Klingeman, supra note 1, at 242-50.

3. See, e.g., Memorial Hosp., 862 F.2d at 1300-03; Neary, 834 P.2d at 127-33 (Kennard, J., dissenting); Fisch, supra note 1, at 606-32.

4. 834 P.2d 119 (Cal. 1992). 
to effectuate a settlement agreement and terminate litigation. ${ }^{5}$ Relying on the notion that "courts exist for litigants" and not the reverse, Neary staked out a "strong presumption in favor of allowing stipulated reversals"7 for California courts.

Though not without its defenders, ${ }^{8}$ the Neary rule has been roundly criticized. In her dissent in the case, Justice Joyce Kennard argued that, because judgments serve a public function beyond mere dispute resolution, litigants should not be able to bargain them away. ${ }^{9}$ Professor Stephen R. Barnett claimed that Neary, while possibly encouraging appellate settlements, would discourage pretrial settlements (which save far more resources), destroy important precedents, and deprive the public of the benefits that flow from judgments. ${ }^{10}$ Within two years, the California Legislature, with the support of the California Judges Association, ${ }^{11}$ passed a bill to restrict the breadth of the Neary rule, ${ }^{12}$ although Governor Pete Wilson ultimately vetoed the measure. ${ }^{13}$ Even the California Supreme Court passed up its first opportunity to fortify the Neary doctrine, in the Lovelace case, ${ }^{14}$ by refusing to facilitate a settlement requiring the erasure of an appellate court opinion.

The United States Supreme Court dealt perhaps the most significant blow to Neary in its 1994 decision in U.S. Bancorp Mortgage Co. v. Bonner Mall Partnership. ${ }^{15}$ Without mentioning Neary, the Court held that, in federal court, mootness of a case's merits by reason of settlement alone does not justify vacatur of a judgment under review; to ob-

5. Id. at 125 .

6. Id. at 123 .

7. Id. at 125 .

8. See, e.g., B.E. Witkin, Introduction: Special Report on California Appellate Justice, 45 Hastings L.J. 425, 425 (1994); Sheila P. Sonenshine, Real Lawyers Settle A Successful Post-Trial Settlement Program in the California Court of Appeal, 26 LOY. L.A. L. REV. 1001, 1003 n.8 (1993).

9. Neary, 834 P.2d at 127 (Kennard, J., dissenting).

10. Barnett, supra note 1 , at 1057-84.

11. Scott Graham, Stipulated Reversals Survive with Wilson Veto of SB 102, THE RECORDER (S.F.), Sept. 28, 1994, at 3.

12. Cal. S. 102, Cal. 1993-94 Reg. Sess. (amending Cal. Civ. Proc. Cone § 128(a)(8)). S. 102 would have prevented California appellate courts from reversing or vacating "a duly entered judgment upon an agreement or stipulation of the parties unless it finds both of the following:

(A) There is no reasonable possibility that the interests of nonparties or the public will be adversely affected by the reversal[; and]

(B) The parties' reasons for requesting reversal outweigh the erosion of public trust that may result from the nullification of a judgment and the risk that the availability of stipulated reversal will reduce the incentive for pretrial settlement."

13. Governor Wilson's veto message asserted that $\mathrm{S}$. 102 would "discourage and in most cases prevent postjudgment settlements, forcing the parties to continue to pursue an appeal even though both sides wish to settle and terminate any further litigation," 14 CAL. REG. L. REP. 208, 216 (Fall 1994), and that "[t]he presumption in favor of settlement should be retained, not reversed." Graham, supra note 11 , at 3 .

14. State ex rel. State Lands Comm'n v. Superior Court (Lovelace), 900 P.2d 648 (Cal. 1995).

15. 115 S. Ct. 386 (1994). 
tain vacatur of a federal judgment, parties on appeal must demonstrate "exceptional circumstances." 16 The procedural posture in Bonner Mall differed from that in Neary since, in Bonner Mall, the parties settled (without a provision for vacatur) after the Supreme Court granted certiorari, and then one party sought vacatur of the Ninth Circuit's judgment. ${ }^{17}$ However, the Court made explicit that its holding applied to joint motions for vacatur as well, stating that "the mere fact that the settlement agreement provides for vacatur" is not an exceptional circumstance justifying vacatur. ${ }^{18}$ Thus, the Court announced a federal rule that was directly contrary to the one adopted for California courts in Neary just two years earlier. Professor Barnett interpreted this as a "ringing rejection of the California Supreme Court's approach."19

Stipulated reversal is a settlement mechanism which masquerades as a judicial decision on the merits. Although the parties have settled their differences before the appeal is ever truly decided, the appellate court disposes of the case by reversing the judgment below, rather than simply dismissing the appeal. The normal connotation of a reversal is that the lower court's judgment does not constitute legal authority. In consequence, the trial court's resolution of issues in controversy cannot be authoritatively relied upon in future litigation. This explains why stipulated reversal is uniquely attractive to litigants who fear that unfavorable findings of fact in one case will bind them in later actions under

16. Id. at 393 .

17. Id. at 389. The other party opposed the motion; at oral argument, its counsel acknowledged that it was really arguing as a "friend of the Court" and had only a "remote[]" interest in preventing vacatur. Official Transcript of the Proceedings Before the United States Supreme Court, U.S. Bancorp Mortgage Co. v. Bonner Mall Partnership, No. 93-714, 1994 WL 761917, at *48 (Oct. 4, 1994) [hereinafter Bonner Mall Transcript].

18. Bonner Mall, $115 \mathrm{~S}$. Ct. at 393. Federal courts have followed this dictum in denying parties' joint motions for vacatur. See, e.g., Bank One Chicago, N.A. v. Midwest Bank \& Trust Co., 85 F.3d 631 (7th Cir. 1996); Keller v. Mobil Corp., 55 F.3d 94, 98-99 (2d Cir. 1995); Nahrebeski v. Cincinnati Milacron Mktg. Co., 41 F.3d 1221, 1222 (8th Cir. 1994); Krolikowski v. Volanti, No. 95 C 1254, 1996 WL 451307, at *2-4 (N.D. Ill. Aug. 7, 1996); Stolz v. Am. Int'l Life Assurance Co., 922 F. Supp. 435, 435-36 (W.D. Wash. 1996); Aetna Cas. and Sur. Co. v. Home Ins. Co., 882 F. Supp. 1355, 1355-58 (S.D.N.Y. 1995); Bailey v. Blue Cross/Blue Shield, 878 F. Supp. 54, 55-56 (E.D. Va. 1995); EFS Mktg., Inc. v. Russ Berrie \& Co., No. 91 Civ. 5515, 1995 WL 77924, at *1 (S.D.N.Y. 1995); Dunkin v. Louisiana-Pacific Corp., I59 F.R.D. 554, 555 (D. Colo. 1995), aff'd, 89 F.3d 849 (10th Cir. 1996); In re Meis-Nachtrab, 200 B.R. 170, 171 (Bankr. N.D. Ohio 1996); In re Hiller, 179 B.R. 253, 257-62 (Bankr. D. Colo. 1994). But see Woodland v. City of Houston, No. 96-20358, 1996 WL 752803, at *1 (5th Cir. Aug. 21, 1996) (vacating a judgment after finding exceptional circumstances); Lindsey v. Metropolitan Life Ins. Co., 929 F. Supp. I435, 1436 (D. Wyo. 1996) (same); Alexander v. Perill, 872 F. Supp. 722, 722 (D. Ariz. 1995) (same). Also, several state courts have relied on Bonner Mall as persuasive authority to deny settlement vacatur. See, e.g., Commissioner of Motor Vehicles v. Demilo and Co., 659 A.2d 148, 157-58 (Conn. 1995); Paramount Communications v. Gibraltar Cas. Co., 623 N.Y.S.2d 850, 850-51 (App. Div. 1995). But see Panterra Corp. v. American Dairy Queen, 908 S.W.2d 300, 300-01 (Tex. C. App. 1995) (distinguishing Bonner Mall as governing only federal procedural law).

19. Scott Graham, No More Buying Adverse Judgments; California Ruling Ignored as High Court Halts Vacatur Practice, The ReCORder (S.F.), Nov. 9, 1994, at 1 (quoting Professor Barnett). 
the doctrine of collateral estoppel: stipulated reversal gives them a chance to relitigate.

This Comment puts aside the task of critiquing Neary, which has been ably accomplished elsewhere, ${ }^{20}$ in order to take up an "important question that the court ducked": should courts grant stipulated reversal when the trial court judgment could give rise to collateral estoppel in other cases? ${ }^{21}$ I answer that, in cases where stipulated reversal would destroy trial court findings that could otherwise be used to preclude relitigation in subsequent cases, courts can and should depart from Neary's presumption and deny stipulated reversal. Efficiency and judicial economy, concerns that Neary cited as justifying stipulated reversal, actually militate against its use to evade preclusion. Moreover, because the public interest in collateral estoppel is "specific, demonstrable, well established, and compelling," ${ }^{22}$ such cases merit invocation of Neary's "extraordinary circumstances" exception.

Part I of this Comment provides the essential doctrinal background by: (1) outlining the modern doctrine of collateral estoppel; (2) discussing the California Supreme Court's creation of a presumption in favor of granting stipulated reversals in Neary; and (3) analyzing how stipulated reversal under Neary threatens to render collateral estoppel ineffective. Part II explains how allowing stipulated reversals to eradicate judgments that could give rise to collateral estoppel does not comport with Neary's dominant policy concerns, efficiency and judicial economy. Part III examines the Neary presumption in favor of stipulated reversal and its "extraordinary circumstances" exception and concludes that a trial court judgment's collateral estoppel effect constitutes a public interest sufficient to justify denying stipulated reversal. Finally, Part IV analyzes the difficulties facing California appellate courts ruling on stipulated reversal motions and proposes measures they can take to determine the role, and protect the vitality, of potential collateral estoppel.

\section{I}

Collateral Estoppel and Stipulated Reversal: StRiPPING a JUdGMENT OF Its PReClusive EFFECT

After developing the relevant doctrinal background, this Part explains the problem posed by stipulated reversal-that it allows litigants to evade the usual collateral estoppel effects of proceeding to judgment. Section A discusses the operation of the doctrine of collateral estoppel,

20. Norman I. Krug Real Estate Invs., Inc. v. Praszker, 28 Cal. Rptr. 2d 498, 504-09 (Ct. App. 1994) (Kline, P.J., concurring); Barnett, supra note 1, at 1061-84.

21. Stephen R. Barnett, Judgments for Sale, L.A. DAlLy J., Aug. 27, 1992, at 6.

22. Neary v. Regents of Univ. of Cal., 834 P.2d 119, 125 (Cal. 1992). 
focusing particularly on its nonmutual form, which is most relevant to the study of stipulated reversal. Section B discusses the procedure of stipulated reversal and the Neary court's rationale for creating a presumption in its favor. Finally, Section $\mathrm{C}$ analyzes the interaction of the two doctrines and concludes that stipulated reversal of a judgment invalidates the preclusive effect it might otherwise have had.

\section{A. The Doctrine of Collateral Estoppel}

\section{General Principles}

Collateral estoppel, or issue preclusion, ${ }^{23}$ is a doctrine that affords special status to certain matters established in a legal action. Part of the doctrine of res judicata, ${ }^{24}$ collateral estoppel grants judgments, once entered, a measure of finality by precluding later relitigation of issues litigated in that action. Bringing litigation of certain matters to a close is thought to serve three goals: judicial economy, since, by preventing wasteful relitigation, the resources of the courts are put to efficient use; public confidence in the judicial system's integrity through prevention of inconsistent judgments; and repose-that is, protecting people from being harassed by vexatious litigation. ${ }^{25}$ Even where those goals are promoted, however, collateral estoppel is not imposed when it would be unfair to prevent a party from drawing into question a matter that has previously been litigated. ${ }^{26}$

The basic prerequisites for application of collateral estoppel are well established. The black-letter law of collateral estoppel, as set forth in section 27 of the Restatement Second of Judgments, provides: "When an issue of fact or law is actually litigated and determined by a valid and final judgment, and the determination is essential to the judgment, the determination is conclusive in a subsequent action between the parties, whether on the same or a different claim." ${ }^{27}$ In Bernhard v. Bank of America National Trust \& Savings Association, ${ }^{28}$ Justice Roger Traynor of the California Supreme Court set out the seminal test for application of collateral estoppel:

23. This Comment uses the terms interchangeably.

24. Literally, "[a] matter adjudged." BLACK's LAW DictionaRY 905 (6th ed. abridged 1991). The term "res judicata" is used inconsistently to describe either the entire family of "former adjudication" or preclusion doctrines (of which collateral estoppel is one type) or the doctrine of claim preclusion, which precludes relitigation of claims raised or waived in prior litigation. See Steven C. Yeazell ex al., Civil Procedure 887 (3d ed. 1992).

25. See Lucido v. Superior Court, 795 P.2d 1223, 1227 (Cal. 1990) (identifying collateral estoppel policies).

26. See Teitelbaum Furs, Inc. v. Dominion Ins. Co., 375 P.2d 439, 441-42 (Cal. 1962) (suggesting that a prior full and fair opportunity to litigate an issue is prerequisite to application of collateral estoppel).

27. REstatement (SECOND) OF JUdGMENTS § 27 (1982).

28. 122 P.2d 892 (Cal. 1942). 
In determining the validity of a plea of [collateral estoppel] three questions are pertinent:

[(1)] Was the issue decided in the prior adjudication identical with the one presented in the action in question?

$[(2)]$ Was there a final judgment on the merits?

[(3)] Was the party against whom the plea is asserted a party or in privity with a party to the prior adjudication ${ }^{29}$

If the answers to all three questions are "yes," then Bernhard permits the prior adjudication's resolution of the issue to preclude reconsideration of the issue in the pending action.

\section{The Mutuality Requirement: Who May Benefit from Preclusion?}

The Restatement Second section 27 test permits preclusion of matters previously litigated only "in a subsequent action between the parties." Those not present in the initial action cannot later benefit from, nor be bound by, collateral estoppel. Limiting collateral estoppel to serial actions between the same parties is known as the doctrine of mutuality. Until a few decades ago, the requirement of mutuality significantly constrained the sweep of collateral estoppel. Today, although section 27 provides for collateral estoppel only where there is mutuality, the Restatement Second has in fact abandoned the mutuality requirement to which the original Restatement of Judgments adhered..$^{30}$ Restatement Second section 29 provides that under certain circumstances those precluded from relitigating an issue under section 27 may also be precluded in actions with those not parties to the prior action. ${ }^{31}$

The formerly universal rule ${ }^{32}$ of mutuality was premised on the principle of due process that a stranger to a proceeding should not later be precluded from challenging issues decided therein. Allowing estoppel under these circumstances would deny a stranger his or her "day in court." ${ }^{33}$ The symmetrical rule preventing a litigant from invoking a past action to which he or she was not a party followed from a sense that it is somehow unfair to allow a litigant who never risked being burdened

29. Id. at 895.

30. RESTATEMENT (FIRST) OF JUDGMENTS § 68(1) (1942) (providing that "[w] here a question of fact essential to the judgment is actually litigated and determined by a valid and final judgment, the determination is conclusive between the parties in a subsequent action on a different cause of action").

31. Restatement (SECOND) OF Judgments \& 29 (1982).

32. Bigelow v. Old Dominion Copper Mining \& Smelting Co., 225 U.S. 111, 127 (1912) ("It is a principle of general elementary law that the estoppel of a judgment must be mutual.").

33. Parklane Hosiery Co. v. Shore, 439 U.S. 322, 327 n.7 (1979) (statiug that "[i]t is a violation of due process for a judgment to be binding on a litigant who was not a party or a privy and therefore has never had an opportunity to be heard"). But see AMERICAN LAW INSTITUTE, CoMpLEX Litigation Project § 5.05 \& cmts. a-b (Proposed Final Draft 1993) (proposing scheme of preclusion of outsiders by the outcome of "complex actions" after court-ordered notice to nonparties, in order to induce intervention, and arguing that due process is satisfied by the scheme). 
by a prior judgment (by being a named or represented party to the litigation) to benefit from that judgment. ${ }^{34}$

In California, the third part of the Bernhard ${ }^{35}$ test for the application of collateral estoppel abrogated the mutuality requirement. While the test requires that the party against whom preclusion is asserted was a party or "privy"36 of a party to the earlier action, it does not require the same of the party invoking preclusion. Thus, in what has come to be known as "nonmutual" preclusion, a stranger to the initial action may later employ its judgment to collaterally estop one who was bound by that action. In justifying this dramatic expansion of estoppel, Justice Traynor wrote that "[n]o satisfactory rationalization has been advanced for the requirement of mutuality." ${ }^{37}$ As the United States Supreme Court would later note, the simplistic notion that it is somehow unfair to allow nonparties to assert collateral estoppel in later actions "fail[s] to recognize the obvious difference in position between a party who has never litigated an issue and one who has fully litigated and lost." ${ }^{38}$ Assuming the fairness of the initial action, it does not seem unfair to deny a litigant additional opportunities against each new opponent after previously litigating an issue and losing. As will be explained shortly, ${ }^{34}$ it is in the area of nonmutual preclusion that stipulated reversal threatens to make its most significant inroads into the law of collateral estoppel.

\section{a. The Offensive/Defensive Distinction}

In analyzing nonmutual collateral estoppel, courts and commentators have routinely drawn a distinction between offensive and defensive use of collateral estoppel. ${ }^{40}$ Defensive collateral estoppel occurs when a defendant attempts to preclude a plaintiff from litigating an issue that the plaintiff has previously litigated unsuccessfully against another

34. See Parklane, 439 U.S. at 327.

35. Bernhard v. Bank of Am. Nat'l Trust \& Sav. Ass'n, 122 P.2d 892, 895 (Cal. 1942). At the federal level, the requirement of mutuality was abandoned by the United States Supreme Court in Blonder-Tongue Lab., Inc. v. Univ. of Ill. Found., 402 U.S. 313 (1971) (permitting "defensive" nonmutual collateral estoppel) and Parklane Hosiery Co. v. Shore, 439 U.S. 322 (1979) (permitting "offensive" nonmutual collateral estoppel).

36. "Privity" is a doctrine used to bind an outsider (a "privy") to the effects of a judgment on the grounds that the outsider's relationship with a party "is 'sufficiently close' so as to justify application of the doctrine of collateral estoppel." Clemmer v. Hartford Ins. Co., 587 P.2d 1098, 1102 (Cal. 1978).

37. Bernhard, 122 P.2d at 895.

38. Parklane, 439 U.S. at 327.

39. See infra Part I.C.3.

40. See, e.g, Parklane, 439 U.S. at 329-33; Michael D. Green, The Inability of Offensive Collateral Estoppel to Fulfill Its Promise: An Examination of Estoppel in Asbestos Litigation, 70 low A L. REv. 141, 150-52 (1984) (analyzing appropriateness of applying offensive collateral estoppel in asbestos litigation). Professor Brainerd Currie was the first to draw the distinction between offensive and defensive collateral estoppel. Brainerd Currie, Mutuality of Collateral Estoppel Limits of the Bernhard Doctrine, 9 StaN. L. Rev. 281, 290 (1957). 
party ${ }^{41}$ in offensive collateral estoppel, the plaintiff seeks to prevent the defendant from litigating an issue that the defendant has previously litigated and lost in an action with another party. ${ }^{42}$ American courts generally are more inclined to permit defensive, rather than offensive, collateral estoppel..$^{43}$ Defensive estoppel is perceived by courts as more effectively promoting the goals of preclusion and possessing less potential for unfairness than its offensive counterpart. ${ }^{44}$

\section{b. Availability of Offensive Collateral Estoppel}

Concerned with issues of judicial economy and fairness, the United States Supreme Court, in Parklane Hosiery Co. v. Shore, ${ }^{45}$ gave offensive collateral estoppel conditional approval-a principle followed today by California courts. The Parklane Court observed that offensive collateral estoppel does not promote judicial economy-through reduction in litigation - in the same way as defensive preclusion. Defensive collateral estoppel denies plaintiffs an opportunity to relitigate issues by "switching adversaries" and thus encourages them to join all potential defendants in the first action. ${ }^{46}$ Offensive preclusion, however, discourages joinder of plaintiffs. Plaintiffs can decline to join similarly situated plaintiffs in an action against a common defendant and later rely on a judgment against the defendant from that action without ever taking the risk of losing on the litigated issue..$^{47}$

Parklane also argued that offensive collateral estoppel may be unfair to defendants in some cases. The defendant might have lacked the incentive to defend the first action vigorously, because, for example, the damages sought were small or future suits raising identical issues were not foreseeable. ${ }^{48}$ The Court found that granting offensive collateral estoppel to a judgment which is inconsistent with another judgment against the defendant is also unfair. ${ }^{49}$ Where the procedural opportunities available to the defendant in the second action are broader than in the initial action, allowing offensive preclusion unfairly prejudices the

41. Parklane, 439 U.S. at 326 n.4.

42. Id.

43. E.H. Schopler, Annotation, Mutuality of Estoppel as Prerequisite of Availability of Doctrine of Collateral Estoppel to a Stranger to the Judgment, 31 A.L.R. 3D 1044, 1072 (1970).

44. Parklane, 439 U.S. at 329-31. But see Craig R. Callen \& David D. Kadue, To Bury Mutuality, Not to Praise It: An Analysis of Collateral Estoppel After Parklane Hosiery Co. v. Shore, 31 HASTINGS L.J. 755 (1980) (questioning the criticisms of offensive collateral estoppel).

45. 439 U.S. 322, 329-3I (1979).

46. Id. at 329-30 (quoting Bemhard v. Bank of Am. Nat'l Trust \& Sav. Ass'n, 122 P.2d 892, 895 (Cal. 1942)).

47. Id.

48. Id. at 330 .

49. Id.; see also Currie, supra note 40 , at 285-86 (describing this situation as "the multipleclaimant anomaly"). 
defendant..$^{50}$ Because of these concerns, Parklane instructed federal trial courts to permit offensive collateral estoppel only as to issues which the defendant "received a 'full and fair' opportunity to litigate" in the first action. ${ }^{51}$

Although the California Supreme Court's Bernhard decision had sweepingly endorsed nonmutual collateral estoppel, the form of preclusion employed in that case was defensive..$^{52}$ Consistent with Parklane's recognition that offensive collateral estoppel is not as meritorious as defensive collateral estoppel, the California appellate courts have been reluctant to permit it. Initially, courts limited Bernhard to its facts and prohibited offensive preclusion altogether. ${ }^{53}$ Eventually they began to permit offensive use, at least where justified under the fairness principles outlined in Parklane. ${ }^{54}$ Although the California Supreme Court has not explicitly ruled on the propriety of offensive nonmutual preclusion, ${ }^{55}$ the court has impliedly sanctioned its use where the "fundamental principles underlying [collateral estoppel]" are served..$^{36}$

The abandonment of the mutuality requirement means that judgments benefit not only current litigants, but also the courts and those who may be litigants in the future. Nonmutual issue preclusion relieves the courts of the necessity of permitting litigants to advance the same rejected position on an issue over and over in seriatim litigation with

50. Parklane, 439 U.S. at $330-31$.

51. Id. at 332 .

52. The Bernhard defendant was able to employ a prior judgment (approving a probate accounting) as collateral estoppel against the plaintiff, who had been a party to the probate proceeding. Bernhard, 122 P.2d at 893-94.

53. See McDougall v. Palo Alto Unified Sch. Dist., 28 Cal. Rptr. 37, 40-42 (Ct. App. 1963) (refusing to apply offensive collateral estoppel in multiple claimant scenario); Nevarov v. Caldwell, 327 P.2d 111, 114-19 (Cal. Ct. App. 1958) (same); David 1. Levine et al., Cases and Materials on California Civil Procedure 522 (1991).

54. See Stolz v. Bank of Am. Nat'l Trust \& Sav. Ass'n, 19 Cal. Rptr. 2d 19, 22-23 (Ct. App. 1993); Estate of Gump, 2 Cal. Rptr. 2d 269, 286 (Ct. App. 1991); Imen v. Glassford, 247 Cal. Rptr. 514, 517-19 (Ct. App. 1988); R.E. Spriggs Co. v. Adolph Coors Co., 156 Cal. Rptr. 738, 744 (Ct. App. 1979) ("Use of collateral estoppel as a sword is not novel.... [T] an anachronism no longer deserving of judicial recognition."); O'Connor v. O'Leary, 56 Cal. Rptr. 1, 4 (Ct. App. 1967) ("[A]pplication of the doctrine of collateral estoppel, absent the element of mutuality, is not dependent upon whether it is asserted offensively or defensively, but upon whether, under the particular circumstances at hand, policy considerations restrict its use."); LEVINE ET AL., supra note 53 , at 522-23.

55. The California Supreme Court's brushing aside of the collateral estoppel issue in Neary because "no nonparty is or will be affected by the trial court judgment", Neary v. Regents of Univ. of Cal., 834 P.2d 119, 125 (Cal. 1992); see also infra notes 96-97 and accompanying text, suggests an implicit assumption that were the judgment to survive, affected nonparties could invoke it to collaterally estop those bound as parties. The parties prevented from relitigating would most likely be the defendants (the University and the veterinarians) because the essential findings were adverse to them. The most likely context in which the defendants would be bound in later litigation would be offensive collateral estoppel (such as another rancher suing them for libel in the reports). Consequently, it is fair to infer that the court generally accepts offensive collateral estoppel.

56. Lucido v. Superior Court, 795 P.2d 1223, 1224 (Cal. 1990). 
new opponents. It can also be a valuable shield or weapon for outsiders $^{57}$ because it reduces the cost and difficulty of proving or defending against a claim. Bernhard's abolition of the mutuality requirement also increased the burdens imposed by judgments: a litigant may bear not only the costs of losing the present suit, but also the likelihood that a loss will generate costly preclusion in future cases involving related issues. As a consequence, we can expect that "the possible preclusive effect of a judgment [would have] an increasingly important role in a party's strategy during settlement negotiations." 58

\section{B. Stipulated Reversal and the Neary Rule}

"Stipulated reversal" is a procedure whereby the parties to an appeal jointly request that the appellate court reverse the trial court's judgment as part of a settlement. ${ }^{59}$ If it grants stipulated reversal, the court of appeal reverses the lower court's judgment without ever considering the merits. A related practice, stipulated "vacatur," has been permitted in some federal and state courts; ${ }^{60}$ under "vacatur" the parties request that the judgment below be "vacated" rather than "reversed." Although slight differences between the effects of these two procedures may exist, ${ }^{61}$ I treat them identically for purposes of this Comment.

Stipulated reversal first gained explicit sanction in California with the California Supreme Court's 1992 decision in Neary v. Regents of the University of California. ${ }^{62}$ Neary established for the first time in any

57. See Warren Freedman, Res Judicata and Collateral Estoppel: Tools for PlaAintiffs and Defendants 61-78 (1988).

58. Elizabeth L. Anstaett, Comment, Is Settlement Conditioned on Vacatur an Option? Should It Be?, 1991 J. DisP. RESOL. 87, 94.

59. Stipulated reversal should be distinguished from dismissal of an appeal (which can be triggered either by the appellant's abandonment of the appeal or a stipulation of the parties to dismiss, Cal. R. CT. 19(b)). Dismissal is the more common manner of disposition for settled appeals. See Neary, 834 P.2d at 128 (Kennard, J., dissenting) ("When notified of a settlement, an appellate court will ordinarily dismiss an appeal as moot.... This is the normal manner in which appellate settlements occur.").

60. See, e.g., U.S. Philips Corp. v. Windmere Corp., 971 F.2d 728, 731 (Fed. Cir. 1992), cert. granted sub nom. Izumi Seimitsu Kogyo Kabushiki Kaisha v. U.S. Philips Corp., 507 U.S. 907, and cert. dismissed, 510 U.S. 27 (1993); Federal Data Corp. v. SMS Data Prods. Group, 819 F.2d 277, 279-80 (Fed. Cir. 1987); Nestle Co. v. Chester's Mkt., Inc., 756 F.2d 280, 282-83 (2d Cir. 1985).

61. See Barnett, supra note 1, at 1065-1068 (discussing possible stronger connotation of "reversal" compared to "vacatur").

62. 834 P.2d 119 (Cal. 1992). The status of stipulated reversal prior to Neary was a matter of some dispute in that case. The Neary majority asserted that California courts of appeal had "routinely" granted stipulated reversals. Id. at 121, 122, 126. Justice Kennard's dissent, id. at 130 (Kennard, J, dissenting), however, noted a published court of appeal opinion, In re Marriage of Shapiro, 114 Cal. Rptr. 277 (Ct. App. 1974), which had denied a motion for stipulated refusal, and Professor Barnett has reported that, since 1990, Division One of the Fourth District Court of Appeal consistently had refused to grant stipulated reversals. Barnett, supra note 1, at 1064 (citing Petition for Review at 3, Neary (No. SO20515)). 
American jurisdiction ${ }^{63}$ that courts should ordinarily grant parties' requests for stipulated reversal. The court held that "when the parties to an action agree to settle their dispute and as part of their settlement stipulate to a reversal of the trial court judgment, the Court of Appeal should grant their request for the stipulated reversal absent a showing of extraordinary circumstances that warrant an exception to this general rule." $" 64$

\section{The Neary Presumption}

In Neary, cattle rancher George Neary brought a libel action against the University of California and three veterinarians employed by the University of California at Davis. To prevent an infestation by the scabies mite, federal and state agricultural agencies had sprayed Neary's herd of pregnant heifers with an insecticide. ${ }^{65}$ After the illness and deaths of many of Neary's cattle, Neary expressed his belief that the toxaphene treatment was responsible. State agricultural officials and Neary agreed to have the veterinarians investigate the matter. ${ }^{66}$ The University, in a published report of the doctors' investigation, concluded that Neary's subpar ranch management had caused the losses. ${ }^{67}$ Neary sued and won a $\$ 7$ million jury verdict. Both sides appealed, but later arrived at a settlement agreement, under which Neary would receive $\$ 3$ million. In return, Neary was to join the defendants in a stipulation to the court of appeal providing that the court would dismiss both appeals with prejudice, vacate the trial court judgment, and direct the trial court to dismiss the action with prejudice. The parties filed a joint application requesting reversal of the trial court judgment and remand to the superior court for dismissal with prejudice..$^{68}$

The First District Court of Appeal denied the application, ${ }^{69}$ holding that neither precedent nor considerations of policy justified reversal of the trial court judgment. ${ }^{70}$ Presiding Justice J. Anthony Kline examined past instances of reversal based on postjudgment events, including settlement, and concluded that they had never been "predicated simply on the desire of the parties to effectuate settlement."71 Moreover, the strong public policy favoring settlement, which is aimed mainly at avoiding

63. See Barnett, supra note 1, at 1033 \& n.1 (stating that stipulated reversal "appear[s] to be unique among courts in this country, if not in the world").

64. Neary, 834 P.2d at 125.

65. Id. at 131 (Kennard, J., dissenting).

66. Id. (Kennard, J., dissenting).

67. Id. at 120 .

68. Id.

69. Neary v. Regents of Univ. of Cal., 278 Cal. Rptr. 773, 778 (Ct. App. 1991), rev'd, 834 P.2d 119 (Cal. 1992).

70. Id. at 775 .

71. Id. 
costs of trial to the public and to litigants, was less compelling when a trial had already been conducted and a judgment rendered, since "massive" amounts of public and private resources had already been expended. ${ }^{72}$ Finally, "reversal of a judgment not thought to be legally erroneous simply to effectuate settlement would trivialize the work of the trial courts and undermine the integrity of the entire judicial process." "73

The California Supreme Court reversed, one justice dissenting. ${ }^{74}$ Justice Marvin Baxter, writing for the court, stated that appellate courts should respect a "strong presumption in favor of allowing stipulated reversals." a stipulated reversal by the Court of Appeal absent a showing of extraordinary circumstances that warrant an exception." ${ }^{36}$ The court justified its creation of the strong presumption in four ways. First, stipulated reversals are consistent with the policy in favor of settlement, which dictates speedy resolution and disposition of disputes to "preclude the need for future expenditures of time and money by the parties and the judiciary." S77 Second, fairuess requires that courts respect parties' choices and assist them in settlement because "courts exist for litigants." Third, it is improper to "treat[] all postjudgment settlements as being equally wasteful."79 For example, judgment may be entered upon a demurrer or summary judgment motion, in which case the trial court will not have expended substantial resources in rendering judgment. $^{80}$ Postjudgment settlements may even be more efficient than prejudgment settlements, which often follow "protracted and costly litigation," but are never "preclude[d] ... on the ground that too much has already been invested." Finally, the court argued that the public

72. Id. at 777 .

73. Id. at 778 .

74. Neary v. Regents of Univ. of Cal., 834 P.2d 119, 126-27 (Cal. 1992).

75. Id. at 125 .

76. Id. at 121 .

77. Id.

78. Id. at 122-23. This is hardly an incontrovertible proposition. Many commentators insist that, even if this is the model the courts often claim to follow, it does not adequately describe the behavior or function of the courts in practice. For example, Professor Melvin Eisenberg has argued that "enrichment of the supply of legal rules," along with dispute resolution, is one of two paramount social functions of courts. Melvin A. Eisenderg, The Nature of the Common Law 4, 6 (1988). Further, Professor Eisenberg posits that establishing legal rules is not merely an "incidental byproduct" of the process of resolving disputes, no matter how often the courts profess that it is so. Id. at 5. Rather, observable patterns of judicial behavior indicate that in fact courts treat enrichment as "desirable in itself." Id. at 6.

79. Neary, 834 P.2d at 123.

80. Id.

81. Id. 
interest is served by stipulated reversal because it assists "the peaceful settlement of disputes and unclogging of court dockets." 82

The Neary court did answer the charge, leveled by the court of appeal, ${ }^{83}$ that allowing stipulated reversals would undermine the integrity of the judicial process. ${ }^{84}$ The court first asserted that the "primary purpose of the public judiciary is 'to afford a forum for the settlement of litigable matters between disputing parties," "85 not to "search for "legal truth." "86 Consequently, as long as stipulated reversal helps the courts resolve the dispute, judicial integrity is not threatened. ${ }^{87}$ Moreover, because "[t]rial courts make no binding precedents," stipulated reversal does not destroy any opinion that could otherwise "provide[] guidance to other courts and litigants." 88 Rather, the majority found that trial "may educate the litigants as to the true value of the case and prompt a settlement;" to the extent that a trial followed by stipulated reversal facilitates "[r]esolution-whether decreed or agreed-...the ultimate object of the litigation process" has been achieved ${ }^{89}$ Finally, stipulated reversal does not "erase or rewrite," "destroy[] or seal[]" the public record of the trial. Since the disposition is pursuant to settlement, "[t]here will be no inference that the jury or trial court erred."

\section{The Neary Exception}

As indicated above, Neary created a strong presumption in favor of granting stipulated reversal requests. However, the court did admit a possible exception, noting that there "might be unusual circumstances in which the public interest would weigh dispositively against a stipulated reversal." Since "[t]he policies favoring settlement are strong and ... the extraordinary-circumstance exception is narrow," the court declared that "some amorphous and speculative public interest" would not warrant denial of a stipulated reversal request. ${ }^{92}$ The Neary majority reminded courts of appeal that the nature of the presumption was such that they "need not expend significant resources [searching for ex-

\footnotetext{
82. Id. at 125.

83. See supra note 73 and accompanying text.

84. Neary, 834 P.2d at 124.

85. Id. (quoting Vecki v. Sorensen, 340 P.2d 1020, 1021 (Cal. Ct. App. 1959)).

86. Id. (quoting Neary v. Regents of Univ. of Cal., 278 Cal. Rptr. 773, 778 (Ct. App. 1991), rev'd, 834 P.2d 119 (Cal. 1992)).

87. Id.

88. Id.

89. Id.

90. Id. The court stated that "[t]0 remove any possible doubt... the appellate court can explicitly state in its order that the reversal is pursuant to settlement and does not constitute either approval or rejection of the trial court's judgment." Id.
}

91. Id. at 125.

92. Id. 
traordinary circumstances weighing against reversal] unless a nonparty comes forward and objects to the settlement for some reason or unless some problem is apparent in the record." ${ }^{993}$ Rather, "[t]o be sufficient to overcome the strong presumption in favor of allowing stipulated reversals, an asserted public interest must be specific, demonstrable, well established, and compelling." might be is a question left open by Neary, to be determined by courts "on a case-by-case basis." 95

Neary did offer one clue as to what might implicate the extraordinary circumstances exception. Stating that "we should avoid advisory opinions," Neary declined to address whether a judgment's potential collateral estoppel impact in other litigation "should be a factor in deciding whether to depart from the strong presumption in favor of allowiug the parties to settle their dispute by seeking a stipulated reversal." ${ }^{.96}$ Based on the parties' representations and its own examination of the record, the court found that "no nonparty is or will be affected by the trial court judgment." "Th Therefore, the court said, "[c]ollateral estoppel is not an issue in this case."

This Comment seeks to resolve the issue that Neary deferred: whether collateral estoppel effects are reason enough to deny stipulated reversal. However, before we can directly address that question, we must examine what effect, if any, that stipulated reversal of a judgment would have on its preclusive force. The next Section takes up that task.

\section{Stipulated Reversal: A Bar to Collateral Estoppel?}

When stipulated reversal is granted, no final judgment emerges. As a consequence, under established collateral estoppel doctrine, the reversal will prevent collateral estoppel in contexts where it would otherwise be permitted. Thus, for litigants who foresee being precluded in subse-

93. Id. at 126 .

94. Id. at 125 .

95. Id.

96. Id.

97. Id. Of course, the veterinarian defendants asserted that they had sought to condition settlement upon reversal of the judgment because they believed it had "severely blemished their professional reputations and, as a result, significantly impaired their ability to function as productive members of the scientific community." Neary v. Regents of Univ. of Cal., 278 Cal. Rptr. 773, 775 (Ct. App. 1991) (quoting defendant's counsel), rev'd, 834 P.2d 119 (Cal. 1992). A person's reputation is, by definition, determined by the perceptions of others. Arguably, therefore, a settlement designed to restore or otherwise affect the defendants' reputations is sought precisely in order to affect nonparties.

98. Neary, 834 P.2d at 125. Professor Barnett has questioned the court's conclusion, both for its dismissal of evidence in the record of other litigation arising out of the pesticide spraying on Neary's ranch and for its reliance upon the litigants' representations. Barnett, supra note 1 , at 1075 n.229. 
quent actions, stipulated reversal will offer a chance to opt out of collateral estoppel.

\section{Is the Reversed Decision a Final Judgment?}

Permitting parties to bargain between themselves for reversal of a judgment offers a possible means to evade the preclusive consequences that might otherwise flow from that judgment. ${ }^{99}$ Yet, given the Neary court's strong insistence that stipulated reversal does not "destroy[] or seal[]" the trial court record, nor create any "inference that the jury or trial court erred," 100 and that the court of appeal can make this explicit by stating "that the reversal is pursuant to settlement and does not constitute ... rejection of the trial court's judgment,"101 one might assume that the trial court's resolution of issues would remain intact for future preclusive use. Unfortunately, Neary and its progeny have not explicitly determined the preclusive effect of judgments reversed by stipulation. ${ }^{102}$ We must rely, therefore, on existing collateral estoppel doctrine for an answer. The use of "reversal" to describe the procedure and the absence of any indication in Neary that the formal consequences of stipulated reversal differ from those of reversal on the merits are instructive. As I will explain, precedent suggests that reversed judgments (including those reversed by stipulation) are unsuitable for preclusion because they do not fulfill the "final judgment" prerequisite to the application of collateral estoppel. ${ }^{103}$

The existence of a final judgment that incorporates the resolution of certain issues is the trigger for precluding future relitigation of those issues. $^{104}$ By statute, California trial court judgments do not obtain

99. See Barnett, supra note 1 , at 1074 ("The question of collateral estoppel is no rare, technical offshoot of stipulated reversal. It lies at the heart of the matter and will demand the court's attention in most cases where stipulated reversal is sought."); Fisch, supra note 1, at 610 ("The most significant cost associated with vacatur is the destruction of a judgment's preclusive effect.").

100. Neary, 834 P.2d at 124 .

101. Id.

102. But see Norman I. Krug Real Estate Invs., Inc. v. Praszker, 28 Cal. Rptr. 2d 498, 502 (Ct. App. 1994) (expressing concern that "reversal of the judgment against [a state-licensed real estate broker], stipulated or not, would effectively deprive the [real estate] cornmissioner of the ability to act" to discipline the broker under California Business and Professions Code section 10177.5, which requires that "a final judgment [be] obtained").

103. See supra note 29 and accompanying text. One commentator who has addressed the impact of stipulated reversal in California on collateral estoppel assumed that the reversed judgment's preclusive effect disappears. Barnett, supra note 1, at 1075. Another has suggested that this result is less than certain, in light of instances of preclusive use of vacated judgments in the federal system. Judith Resnik, Whose Judgment? Vacating Judgments, Preferences for Settlement, and the Role of Adjudication at the Close of the Twentieth Century, 41 UCLA L. REv. 1471, 1511 (1994); see also infra Part I.C.2.

104. See Louie Queriolo Trucking, Inc. v. Superior Court, 60 Cal. Rptr. 389, 392 (Ct. App. 1967) ("Before the doctrine of res judicata can apply or be invoked, there must be a subsisting judgment or final order.... The force of an estoppel by judgment resides in the judgment itself ....") (quoting 
"final" status for preclusive purposes until affirmance on appeal or passage of the time for appeal..$^{105}$ Thus, a trial court judgment that has been appealed is not final and not available for collateral estoppel.

If a stipulated reversal is entered following appeal of the trial court judgment, the reversal itself would seem to prevent the judgment from ever attaining finality. "'Reversal' connotes the affirmative rejection of a judgment." 105 Certainly, that which has been "rejected" cannot be deemed "final." In the few cases in which a party has attempted to invoke an "unqualifiedly reversed" trial court judgment, California courts have held that the judgment has no preclusive effect. ${ }^{107}$ Reporting California law, Witkin states that "[t]he effect of an unqualified reversal ('The judgment is reversed') is to vacate the judgment, and to leave the case 'at large' ... as if it had never been tried, and as if no judgment had ever been rendered."108 Therefore, unless a stipulated reversal is to be treated differently for preclusive purposes than an unqualified reversal, ${ }^{109}$ no final judgment can emerge from a stipulated reversal. We can thus expect future California courts facing relitigation of the same issues to decline to accord the reversed judgment, deprived of finality, collateral estoppel effect.

In contrast to the result of stipulated reversal, trial court judgments are generally given final judgment treatment if never appealed. Moreover, settlement on appeal does not always prevent the trial judgment from becoming final. When the settlement merely provides for dis-

29 CAL. JuR. 2D Judgments \$ 217, at 171 (1952)).

105. Cal. Civ. Proc. Code $\S 1049$ (West 1980) provides that "[a]n action is deemed to be pending from the time of its commencement until its final determination on appeal, or until the time for appeal has passed, unless the judgment is sooner satisfied." This has been construed to mean that "[u]nder the California rule, [a] judgment ... is not final for purposes of res judicata during the pendency of and until the resolution of the appeal." Agarwal v. Johnson, 603 P.2d 58, 72 n.11 (Cal. 1979). See also Sandoval v. Superior Court, 190 Cal. Rptr. 29, 32 (Ct. App. 1983) (noting that, under Califomia law, "pending appeal a trial court judgment is not final and will not be given res judicata effect"). This is contrary to the federal rule, under which a judgment once rendered is final for res judicata purposes until reversed, modified, or set aside. See Calhoun v. Franchise Tax Bd., 574 P.2d 763,765 (Cal. 1978) (noting the contrast and citing Stoll v. Gottlieb, 305 U.S. 165, 170 (1938), for the federal rule).

106. Krug, $28 \mathrm{Cal}$. Rptr. $2 \mathrm{~d}$ at 503.

107. State v. Savings Union Bank \& Trust Co., 199 P. 26, 28 (Cal. 1921) (holding reversed judgment has no preclusive effect); 40 CAL. JuR. 3D (REv.) Part 2 Judgments $\$ 136$, at 179 (1995); see also Grain Dealers Mut. Ins. Co. v. Marino, 246 Cal. Rptr. 410, 412-I3 (Ct. App. 1988) (holding criminal conviction has no preclusive effect after habeas corpus relief "obliterated" judgment).

108. 9 B.E. Witkin, California Procedure Appeal $\$ 625$ (3d ed. 1985).

109. Given the Neary court's disclaimers as to the limited message sent by a stipulated reversal, see supra note 90 and accompanying text, this is arguably possible. However, the court easily could have explained the preclusive effect of a judgment reversed by stipulation when it said that "[w]hatever conclusions the public wishes to draw from the litigation can still be drawn after the reversal." Neary v. Regents of Univ. of Cal., 834 P.2d 119, 124 (Cal. 1992) (emphasis added). That it chose not to may suggest that the conclusions that a court could draw in a subsequent case would differ after stipulated reversal. 
missal of the appeal ("the normal manner in which appellate judgments occur"110), the trial court judgment will become a final judgment under a line of pre-Neary California cases, beginning with Sandoval $v$. Superior Court. ${ }^{111}$ In Sandoval, the leading case, a plaintiff's judgment was appealed. Prior to a ruling on the merits, the "appeal [was] settled favorably to the plaintiff and thereafter dismissed."112 Sandoval held that the judgment "reemerge[d] with sufficient finality to permit the application of collateral estoppel." "[W] "[Wen the agreement to dismiss with prejudice is part of a substantial settlement in plaintiff's favor," the Sandoval court said, it "can fairly be construed as a judgment favoring plaintiff on the merits." of "final judgment" in Restatement Second of Judgments section 13: "any prior adjudication of an issue ... that is determined to be sufficiently firm to be accorded conclusive effect," that is, "the "last word' of the rendering court."115 The California Supreme Court approved the Sandoval analysis in Producers Dairy Delivery Co. v. Sentry Insurance Co. ${ }^{16}$ Thus, under California law, it now appears that the trial judgment emerges as a final judgment when an appellate settlement favoring the victor below triggers dismissal of the appeal.

In sum, existing California doctrine indicates that the collateral estoppel effects of stipulated reversal and dismissal upon appellate settlement are quite dissimilar: stipulated reversal prevents a final judgment, so that no preclusion results, while dismissal of the appeal makes a judgment final, permitting preclusion. Stipulated reversal thus presents a unique settlement opportunity for the appellant: if it fears future preclusion on the basis of an unfavorable trial court judgment, it can negotiate a settlement that allows it to escape preclusion by securing the appellee's and the court's consent to a reversal instead of dismissal.

\section{The Rule in Other Jurisdictions}

Because a California court's judgment must be accorded collateral estoppel treatment in other states' courts and federal courts, ${ }^{117}$ and those

110. Neary, 834 P.2d at 128 (Kennard, J., dissenting).

111. 190 Cal. Rptr. 29 (Ct. App. 1983).

112. Id. at 32 .

113. Id. The Sandoval court's use of the word "reemerge" to describe this process is a misnomer, since the trial court judgment could never have "emerged" before with finality under the California rule that judgments pending appeal are not final. See supra note 105 and accompanying text.

114. Sandoval, 190 Cal. Rptr. at 34.

115. Restatement (SECOND) OF JUDGMENTS $§ 13 \& \mathrm{cmt}$. a (1982).

116. 718 P.2d 920, 924 (Cal. 1986) (agreeing "with the analysis set forth in Sandoval").

117. As to sister state courts, the Federal Constitution's Full Faith and Credit Clause provides that "Full Faith and Credit shall be given in each State to the public Acts, Records, and judicial Proceedings of every other State." U.S. CoNST. art. IV, § I. As to federal courts, section 1738 of the 
courts must "treat [the] ... judgment with the same respect that it would receive in the courts of the rendering state," jurisdictions regarding the preclusive use of judgments vacated or reversed to facilitate settlement cannot govern the collateral estoppel effect of a California judgment reversed by stipulation. However, the approaches of other jurisdictions warrant consideration since Neary did not explicate a preclusion rule for stipulated reversals and, in erecting its presumption in favor of stipulated reversal, relied in part on persuasive federal precedent. ${ }^{119}$ The courts that have considered this matter (even those hostile to vacatur and stipulated reversal) almost uniformly have determined that a vacated judgment is not to be given preclusive effect, ${ }^{120}$ notwithstanding the fact that the policies underlying collateral estoppel should otherwise prevent the party that obtained vacatur from relitigating the issue. ${ }^{121}$ Indeed, in the recent Bonner Mall case before the U.S. Supreme Court, the Solicitor General asserted that this is the "prevailing view."122

Amidst the virtual unanimity on this issue, a few authorities support reliance on a vacated prior judgment for preclusive effect. ${ }^{123}$ Perhaps

Federal Judicial Code provides that "[t]he records and judicial proceedings of any court of any ... State, Territory, or Possession [of the United States] .... shall have the same full faith and credit in every court within the United States and its Territories and Possessions as they have by law or usage in the courts . . from which they are taken." 28 U.S.C. $\$ 1738$ (1994).

118. Matsushita Elec. Indus. Co. v. Epstein, 116 S. Ct. 873, 877 (1996).

119. As Professor Bamett has noted, Barnett, supra note 1, at 1067, at the time Neary was decided, the federal circuits were actually divided on the vacatur question, but Neary cited only the decisions of the two circuits that had adopted the minority position in favor of granting routine stipulated vacatur. See Federal Data Corp. v. SMS Data Prods. Group, 819 F.2d 277, 278 (Fed. Cir. 1987); Nestle Co. v. Chester's Market, 756 F.2d 280, 282 (2d Cir. 1985). Neary even asserted a U.S. Supreme Court practice of "sumınarily vacat[ing] judgments in cases settled while pending on appeal." Neary, 834 P.2d at 121 (quoting Nestle, 756 F.2d at 282). In the wake of Bonner Mall, neither the circuit court precedent nor the purported U.S. Supreme Court practice seems particularly solid. See U.S. Bancorp Mortgage Co. v. Bonner Mall Partnership, 115 S. Ct. 386, 390-93 (1994).

120. For example, recently, the Federal Circuit stated that a "vacated judgment has no collateral estoppel or res judicata effect" in affirming an Illinois district court's reinstatement of an unfair competition claim after the vacatur of a Florida district court judgment (which had previously been used to preclude the plaintiff from pursuing its claim in the Illinois court). U.S. Philips Corp. v. Sears Roebuck \& Co., 55 F.3d 592, 598 (Fed. Cir. 1995). See also United States v. Munsingwear, 1nc., 340 U.S. 36, 39-40 (1950); Pontarelli Limousine, Inc. v. City of Chicago, 929 F.2d 339, 340 (7th Cir. 1991); Savidge v. Fincannon, 836 F.2d 898, 906 \& n.33 (5th Cir. 1988); No East-West Highway Comm., Inc. v. Chandler, 767 F.2d 21, 24 (1st Cir. 1985); Dodrill v. Ludt, 764 F.2d 442, 444 (6th Cir. 1985); Quarles v. Sager, 687 F.2d 344, 346 (11th Cir. 1982); DeNafo v. Finch, 436 F.2d 737, 740 (3d Cir. 1971).

121. See Harris Trust \& Sav. Bank v. John Hancock Mut. Life Ins. Co., 722 F. Supp. 998, 1009 (S.D.N.Y. 1989).

122. Brief for the United States as Amicus Curiae Supporting Petitioner at 19 n. I7, U.S. Bancorp Mortgage Co. v. Bonner Mall Partnership, 115 S. Ct. 386 (1994) (No. 93-714) (citing cases and commentaries).

123. One commentator has argued as follows:

When the parties voluntarily end their litigation through settlement and vacatur, a future court may apply issue preclusion, given that the parties had an opportunity to litigate 
the most widely cited federal case in which preclusion followed vacatur is Chemetron Corp. v. Business Funds, Inc. ${ }^{124}$ There, offensive collateral estoppel was permitted on the basis of an earlier action in which the parties had effected, before entry of final judgment, settlement vacatur of the judge's detailed findings against the defendant. ${ }^{125}$ The Chemetron court decided that preclusion was appropriate, since the prior litigation had reached sufficient finality, despite the absence of a final judgment, to implicate the policies of collateral estoppel. ${ }^{126}$ An analogous line of California cases invoking the Sandoval doctrine permitted preclusion based on a judgment vacated by stipulation. ${ }^{127}$ In these cases, however, the trial court judgments were not the "last word," as Sandoval and the Restatement require for a judgment to be deemed final. Rather, the vacatur of the judgments, a substantive disposition of the case unlike dismissal or remand, was the "last word." Thus, it is difficult to understand how the trial court judgments in these post-Sandoval cases were "sufficiently firm" to support collateral estoppel.

Another case in which a federal court granted preclusive effect to a vacated judgment is Bates v. Union Oil Co., ${ }^{128}$ in which the Ninth Circuit was presented with the appeal of a suit by retail gasoline dealers against their supplier, Union Oil. Granting the plaintiffs' summary judgment motion, the district court had applied collateral estoppel to resolve the issues of liability and punitive damages against Union Oil. ${ }^{129}$ The judgment relied upon had been rendered by the same district court judge in an earlier franchisee suit, Amos v. Union Oil Co. ${ }^{130}$ In Amos, while appeal was pending, the parties reached a settlement conditioned on vacatur and the case was remanded to the district court, which granted vacatur. ${ }^{131}$ However, the Amos judge failed to apply the Ninth Circuit's balancing test-weighing finality against the right to relitigate unreviewed disputes-to determine the appropriateness of vacatur. ${ }^{132}$ In

fully and fairly their dispute. If the parties were fully heard, if the court's opinion were reasoned and if the decision were appealable, then the decision could be considered final for the purpose of preclusion.

Klingeman, supra note 1 , at 248 (footnotes omitted).

124. 682 F.2d 1149 (5th Cir. 1982), vacated on other grounds and remanded, 460 U.S. 1007 , prior opinion adhered to on remand, 718 F.2d 725 (5th Cir. 1983). Chemetron is summarized by Fisch, supra note 1, at 618-19.

125. Chemetron, 682 F.2d at $1187-88$.

126. Id. at 1191-92.

127. See, e.g., Stonewall Ins. Co. v. City of Palos Verdes Estates, 54 Cal. Rptr. 2d 176, 191 (Ct. App. 1996); City of Laguna Beach v. Mead Reinsurance Corp., 276 Cal. Rptr. 438, 443-44 (Ct. App. 1990).

128. 944 F.2d 647 (9th Cir. 1991).

129. Id. at 649 .

130. 663 F. Supp. 1027 (D. Or. 1987).

131. Bates, 944 F.2d at 649 .

132. Id. at 650. Ringsby Truck Lines, Inc. $y$. Western Conference of Teamsters, 686 F.2d 720 (9th Cir. 1982), established the Ninth Circuit's balancing test for deciding vacatur motions: the court is to 
Bates, the Ninth Circuit held that issue preclusion could still apply, even though the judgment was vacated. ${ }^{133}$ Applying its balancing test, the court then upheld issue preclusion in the Bates case. ${ }^{134}$

The approach of Chemetron and Bates should not be applied to stipulated reversals. ${ }^{135}$ First, allowing the reversed judgment to have preclusive effect is unlikely to accord with the deciding court's understanding of what it was doing. Issuing a "reversal," by definition, entails "annulling or setting aside"136 the judgment. Clearly, the appellate court could have chosen to dismiss, a far less drastic disposition than reversal, if it wished to invest the lower court's judgment with final judgment status. ${ }^{137}$ The decision to grant reversal instead must imply that it was willing to undo the judgment below. Moreover, given that avoiding the issue preclusive effect of a judgment is generally identified as the primary reason stipulated reversal or vacatur is sought, it is quite clear that parties requesting the disposition expect to deprive the judgment of collateral estoppel effect. ${ }^{138}$ Consequently, allowing preclusion after stipulated reversal denies the burdened party the benefit of its bargain (pursuant to which it abandoned its right to appeal on the merits). ${ }^{139}$ Put simply, if stipulated reversal amounts to nothing more than

balance "the competing values of finality of judgment and right to relitigation of unreviewed disputes." Id. at 722; see also National Union Fire Ins. Co. v. Seafirst Corp., 891 F.2d 762 (9th Cir. 1989); Allard v. DeLorean, 884 F.2d 464 (9th Cir. 1989).

133. Bates, 944 F.2d at 650 .

134. Id.

135. Both have been criticized, even by critics of vacatur, mainly for the reasons that follow in the text. Regarding Chemetron, see Hughes v. Santa Fe Int'l Corp., 847 F.2d 239, 242 (5th Cir. 1988) (statement by same circuit that Chemetron lacks precedential force); Fisch, supra note 1, at 619-620; see also Dodrill v. Ludt, 764 F.2d 442, 444 (6th Cir. 1985) (disapproving issue preclusion for vacated judgments). Regarding Bates, see MichaEl E Tigar, FEDERAL APPEALs: JuRIsDiction aND Practice $\S 5.16$, at 243 (2d ed. 1993).

136. BlaCK's LAW DictionaRY, supra note 24, at 915. See also Barnett, supra note 1, at 1067 68 (discussing the connotations of "reversing"); supra note 61 and accompanying text.

137. See Cal. Civ. Proc. Code $\S 913$ (West 1980); Cal. R. CT. 19; Sandoval v. Superior Court, 190 Cal. Rptr. 29, 32 (Ct. App. 1983) ("[O]nce the appeal is settled... and thereafter dismissed ... the trial court judgment reemerges with sufficient finality to permit the application of collateral estoppel."); 9 WITKIN, supra note 108, Appeal $\S \$ 528-529$ ( 913 gives trial court judgment final judgment status when appeal dismissed).

138. See Fisch, supra note 1, at 616 ("Destruction of an adverse judgment's collateral estoppel effect is the most common reason for a party to seek vacatur."); Norman I. Krug Real Estate Invs., Inc. v. Praszker, 28 Cal. Rptr. 2d 498, 506 (Ct. App. 1994) (Kline, P.J., concurring) ("The most common reason parties seek vacatur ... is to destroy a judgment's collateral estoppel effect." (citations and footnote omitted)).

139. See Fisch, supra note 1, at 616; Stuart N. Rappaport, Note, Collateral Estoppel Effects of Judgments Vacated Pursuant to Settlement, 1987 U. ILL. L. Rev. 731, 744; see also Jill E. Fisch, The Vanishing Precedent: Eduardo Meets Vacatur, 70 Notre DAME L. Rev. 325, 344 (1994) [hereinafter Fisch, Vanishing Precedent] ("[1]f reliance on vacated opinions became sufficiently widespread, vacatur would have little value to litigants considering settlement after trial."); William D. Zeller, Note, Avoiding Issue Preclusion by Settlement Conditioned upon the Vacatur of Entered Judgments, 96 YALE L.J. 860, 863-64 (1987) ("[P]ermitting a second forum to preclude relitigation of 
dismissal of an appeal by stipulation of the parties, there would be little reason for parties to ever seek it instead of dismissal. ${ }^{140}$ Even if collateral estoppel could be applied after a stipulated reversal, it will frequently be difficult for courts to implement. Case reporter publishers frequently fail to report the reason for the decision to reverse. Accordingly, subsequent courts are often unable to determine whether the basis for a reversal was a stipulation or some other reason, such as mootness or a defect in the lower court judgment, which would not justify collateral estoppel. ${ }^{141}$

\section{The Impact of Stipulated Reversal on Collateral Estoppel}

The foregoing demonstrates that stipulated reversal should deprive a trial court judgment of collateral estoppel effect. We can now construct a more concrete scenario illustrating the interaction of collateral estoppel and stipulated reversal. A party burdened by an adverse trial court judgment can eliminate preclusion in later cases by appealing, and subsequently negotiating a settlement conditioned on stipulated reversal. If the parties' motion for stipulated reversal is granted, the absence of a final judgment will permit relitigation of the same issues in subsequent cases.

In theory, this procedure could thwart application of collateral estoppel in both its mutual and nonmutual variants. However, in the mutual estoppel context, where a judgment by which both parties were bound in a prior action is invoked to preclude relitigation of issues in a subsequent action between the same parties, stipulated reversal is quite unlikely to have a significant independent impact. Parties are permitted to contractually prevent future litigation between themselves involving

issues contained in a vacated judgment would reduce settlement conditioned on vacatur to simple settlement.").

140. Even if stipulated reversal were equivalent to dismissal for purposes of future issue preclusion, an appellant might still seek it if any precedential value of the judgment could be erased or as a way of escaping the reputational disadvantages of an adverse judgment, as the veterinarian defendants sought to do in Neary. See supra note 97.

141. See Fisch, supra note 1, at $616,620 \mathrm{n} .163$ (discussing inability of subsequent courts to discern basis for vacatur in the prior case, especially given practices of major case publishers). Although Neary contemplated that trial courts would make explicit the basis for reversal, see supra notes 90, 100-101 and accompanying text, at least one California Court of Appeal decision created such a risk for subsequent courts by failing to state that its reversal was pursuant to settlement. In Henry v. Monaghan, 40 Cal. Rptr. 2 d 655 (Ct. App. 1995), officially depublished pursuant to CAL. R. CT. 976(d), a malpractice case, the Fourth District granted a stipulated reversal request as to the summary judgment in the accountant defendants' favor while also reversing the summary judgment in the attorney defendants' favor on the merits. Id. at 655-59. Although the court's opinion cited Neary and discussed its consideration of the stipulated reversal request, id. at 655-56, the "Disposition" section stated only that "[t]he summary judgment is reversed." Id. at 659 . The entry in the Court of Appeal minutes, published in the California Advance Sheets, is similarly uninformative. Henry v. Monaghan, No. D018303 (Cal. Ct. App. 4th, May 3, 1995) in 21 Cal. Official Reports, Adv. Sheets, Court of Appeal Minutes 42 (Aug. 3, 1995). 
the same issues and render the judgment of no effect inter $s e^{142}$ and the parties' settlement of the first case (under which they petitioned the court for stipulated reversal) will probably contain a release of all claims arising from the subject matter of the litigation and an agreement not to plead the judgment as collateral estoppel in a subsequent action. Even if they have not done so, it seems unlikely that a party would bargain away significant future preclusive benefits against its opponent without extracting some form of compensation for its loss. Consequently, reversal of the judgment should not impact any future controversies between the same parties.

By contrast, stipulated reversal will most drastically affect judgments' preclusive effects in actions between the litigant that sought reversal and third parties-that is, in the context of nonmutual collateral estoppel. Reversal of a final judgment that had previously resolved an issue unfavorably to the appellant will prevent strangers to the first action from later using the prior resolution against the appellant. Instead, these newcomers will have to undertake the costly, difficult process of prosecuting or defending in relitigation, and the courts will have to endure a wasteful retrial.

Moreover, the procedural instructions given by the Neary court to appellate courts ruling on stipulated reversal requests suggest that, in many cases, judgments which could have nonmutual preclusive effects will be nullified. Neary instructed courts of appeal to grant stipulated reversal automatically, "unless a nonparty comes forward and objects to the settlement for some reason or unless some problem is apparent in the record." ${ }^{143}$ This makes it clear that the protections against eradicating preclusive benefits that accrue to outsiders are far weaker than those safeguarding the interests of the parties in future mutual collateral estoppel. Under Neary's passivity instructions, a party that wishes to preserve a judgment's preclusive effects need only decline a stipulated reversal settlement offer; however, an outsider that wishes to do the same must learn of the proceedings, petition to intervene, and prevail upon the court to deny the reversal motion.

The potential damage to the doctrine of collateral estoppel is apparent: whenever a party to an initially unfavorable determination of an issue foresees adverse preclusion in subsequent actions, stipulated reversal provides that party an opportunity to purchase a second "bite at the apple" by merely buying its victorious adversary's acquiescence in a motion for reversal. As a result, stipulated reversal, if unchecked, could render collateral estoppel ineffective in the very cases in which it is

142. See In re Memorial Hosp., 862 F.2d 1299, 1303 (7th Cir. 1988); Fisch, supra note 1, at 610 n.116.

143. Neary v. Regents of Univ. of Cal., 834 P.2d 119, 126 (Cal. 1992). 
likely to make a difference. The remainder of this Comment is devoted to examining why stipulated reversal should not be allowed to subdue collateral estoppel in this way, first analyzing collateral estoppel's consistency with the efficiency concerns underlying the Neary decision and then explaining how the beneficial effects of collateral estoppel satisfy the Neary rule's extraordinary circumstances exception.

II

\section{JUdicial ECONOMY: THE EFFICIENCY OF COLlateral EstOPPEL}

Despite the strong presumption of Neary, courts should deny stipulated reversal where the effect would be to prevent potential collateral estoppel. The policy concerns that Neary identified to justify the granting of stipulated reversal instead favor its denial when it is sought to prevent collateral estoppel. Moreover, the public interest in preservation of collateral estoppel effects warrants invocation of Neary's extraordinary circumstances exception. This Part examines the first rationale, and Part III discusses the second.

As previously discussed, the Neary court erected its "strong presumption" in favor of granting stipulated reversal on the basis of four arguments: (1) the policy in favor of settlement, respected because of its potential to preserve the resources of litigants and the judicial system; (2) the belief that "courts exist for litigants" and thus owe deference to their interests; (3) the view that courts do not and should not erect barriers to settlement that turn on the court resources already consumed or the rendering of a judgment; and (4) the public interest in peaceful dispute resolution and unclogging the courts. ${ }^{144}$ The court gave the most emphasis and ink to stipulated reversal's conformity with the prosettlement policy. In this Part, I will argue that careful examination of this policy concern, thought in Neary to favor stipulated reversal, actually leads to the conclusion that denial of that procedure is in order when to grant it would invalidate likely collateral estoppel effects of the judgment.

\section{A. Collateral Estoppel's Efficiency Rationale}

A major justification for collateral estoppel is preventing needless repeat litigation. ${ }^{145}$ "The rule is based upon the sound public policy of limiting litigation by preventing a party who has had one fair trial on an issue from again drawing it into controversy." 146 Relitigation of issues, when the initial proceeding was not defective, forces additional con-

144. See supra notes 77-82 and accompanying text.

145. Clemmer v. Hartford Ins. Co., 587 P.2d 1098, 1103 (Cal. 1978).

146. Bernhard v. Bank of Am. Nat'1 Trust \& Sav. Ass'n, 122 P.2d 892, 894 (Cal. 1942). 
sumption of courts' and litigants' resources. Absent due process concerns that prevent binding a litigant by a prior judgment to which it was a stranger, such duplication of efforts is wasteful. Thus, collateral estoppel serves efficiency concerns by "protect[ing] ... adversaries from the expense and vexation attending multiple lawsuits [and] conserv[ing] judicial resources." 147

\section{B. The Policy in Favor of Settlement: Efficiency and Judicial Economy}

According to Neary, denying a stipulated reversal request is " "wasteful of the resources of the judiciary" "148 and the parties since it forces the parties to continue to litigate, and the court to oversee and decide their dispute unnecessarily. This proposition may hold true when viewing individual cases in isolation. Denying stipulated reversal foregoes a potential terminus of litigation and, unless the parties can immediately resolve their dispute another way, ${ }^{149}$ additional judicial time and effort will be consumed. However, this analysis ignores the waste of judicial resources caused by the loss of a judgment's collateral estoppel consequences due to stipulated reversal. To the extent that something valuable is sacrificed in effectuating a settlement, settlement is not an indisputable good, but a tradeoff. ${ }^{150}$ That tradeoff may entail the sig-

147. Montana v. United States, 440 U.S. 147, 153 (1979).

148. Neary, 834 P.2d at 121 (quoting Federal Data Corp. v. SMS Data Prods. Group, 819 F.2d 277, 280 (Fed. Cir. 1987)).

149. Of course, there is no way of knowing whether parties would quickly reach another settlement if stipulated reversal could not be obtained. See id. at 129 (Kennard, J., dissenting); Barnett, supra note 1 , at 1069 . When the economic incentives of the litigants are considered, the prospect appears quite unlikely. If rational parties reach a settlement requiring a stipulation for reversal, this means that they both expect the gain to be had from the agreement is greater (or the loss smaller) than proceeding with litigation. See infra notes 162-67 and accompanying text (discussing economic model of settlement behavior). The existence of the judgment below is a bargaining chip in the appellee's favor, since the collateral effects of that judgment (from collateral estoppel or otherwise), if affirmed, will burden the appellant. The appellee thus has an opportunity to receive settlement dollars in excliange for a stipulation that does it no harm, since it has no interest in the future preclusive effect of the judgment. See Fisch, supra note 1, at 639-40; Green, supra note 40, at 200 n.328. Denying stipulated reversal means that the appellee will be unable to profit from the appellant's dread of these collateral effects. If the collateral consequences are worth a lot to the appellant, the appellant's settlement offer that follows the denial of stipulated reversal should be a good deal smaller (in dollars and cents) than the reversal-based offer. The appellee's expected benefit from continuing to litigate may exceed this amount, prompting a rejection of the settlement offer.

150. In light of the consensus in favor of settlement demonstrated by the Neary majority ("Tlie need for settlements is greater than ever before," Neary, 834 P.2d at 121) and the Neary dissenter ("[T]he judiciary should actively encourage settlement at every stage of litigation," id. at 128 (Kennard, J., dissenting)), this assertion may seem surprising. However, there is a significant body of legal scholarship, most notably the work of Professor Owen Fiss, dedicated to exposing the drawbacks of settlement. See Owen M. Fiss, Out of Eden, 94 YALE L.J. 1669 (1985); Owen M. Fiss, Against Settlement, 93 YALE L.J. 1073 (1984). 
nificant loss of the judgment's collateral estoppel effect. As discussed earlier, collateral estoppel (particularly in the nonmutual context) has been championed mainly as a means of judicial economy-by preventing a party from relitigating an issue that it has previously litigated and lost, the courts are freed from expending resources on needless litigation. Thus, a comprehensive examination of the efficiencies generated by stipulated reversal requires an investigation into the attendant judicial inefficiencies of relitigation that will result from the loss of collateral estoppel effects.

\section{Simplifying Subsequent Trials}

The most obvious way in which collateral estoppel can serve judicial economy is in limiting the issues to be determined in closely related subsequent trials. ${ }^{151}$ When a final judgment has collateral estoppel effect against a bound party, a trial court in a subsequent action presented with an issue determined in the prior action can treat the issue as established and grant partial summary judgment. The court is then free to consider the novel issues raised by the suit.

An example illustrates the savings of time and resources for the court: suppose $\mathrm{P} 1$ and $\mathrm{P} 2$ are both consumers who have developed cancer, allegedly from using a new personal hygiene product manufactured and distributed by D. P1 sues D for damages alleging that D is strictly liable ${ }^{152}$ for his lost wages, medical bills, pain and suffering, and the like, on the theory that D's product was unreasonably dangerous and caused his cancer. After extensive expert testimony presented by both sides at trial regarding the product's dangerousness and the state of medical knowledge concerning whether or not the product's ingredients are carcinogenic, as well as individualized issues such as potential other causes of P1's illness and damages, the jury renders a verdict for P1 and the court enters judgment for P1 which is affirmed on appeal. When P2 sues $\mathrm{D}$, the issue of the product's dangerousness may be taken as established if P2 moves for summary judgment on the basis of offensive nonmutual collateral estoppel. Consequently, the only real issues for trial will be defenses unique to $\mathrm{P} 2$ and damages. ${ }^{153}$ In this way, the court in P2's suit is freed from reconsidering a complex, time-consuming is-

151. See Green, supra note 40 , at 178-79.

152. See Greenman v. Yuba Power Prods., Inc., 377 P.2d 897 (Cal. 1963) (establishing strict liability for manufacturers of defective products); RESTATEMENT (SECOND) OF TORTS $\S 402 A$ (1964) (same).

153. Some commentators argue that litigating the issue of whether collateral estoppel should be permitted will tend to increase the cost of litigation. See, e.g., Green, supra note 40, at 185-189. Some also argue that, in trying the issue of damages, especially if punitive damages are sought, P2's attorneys will still "present evidence of [D's] culpability and liability, cven if legally irrelevant, because of the impact on the jury's assessment of damages." See, e.g., id. at 179. 
sue. However, if during the appeal, D had entered a settlement with P1 requiring a stipulated reversal, the $\mathrm{P} 2$ vs. $\mathrm{D}$ action would have to duplicate the efforts of P1 vs. D in resolving the issue of the product's dangerousness.

With the judicial economy that collateral estoppel enables now made concrete, we are in a position to project whether the efficiency gains from stipulated reversal are likely to be greater. The most significant distinction between the two cases is the level at which additional litigation is avoided. Collateral estoppel eliminates needless judicial efforts at the trial court level, while stipulated reversal prevents further appellate proceedings. It seems likely that the consumption of trial court resources is much more costly than consumption at the appellate level, ${ }^{154}$ since in general much more court time and personnel are required for trial. Indeed, in Neary, the court of appeal noted that "the extravagant expenditures of time and money" incurred in trying that case "dwarf[ed]" those which would be necessary to decide the appeal on the merits. ${ }^{15 s}$

In addition, while stipulated reversal can bring only one case to an end, collateral estoppel may reduce trial time in many cases. For example, in the scenario outlined above, numerous consumers of D's product are likely to bring claims against $\mathrm{D}$. The finding of product dangerousness encompassed in P1's judgment against $D$, if not reversed, could be used to estop $D$ in each action, undoubtedly saving courts and multiple plaintiffs far more resources than if stipulated reversal were permitted and the issue had to be relitigated in each case. D might seek stipulated reversal in each case, except of course the last one.

Moreover, the savings to the court of appeal from stipulated reversal may turn out to be illusory. If stipulated reversal merely defers determination of the issues until the next case, which could also involve an appeal, then the appellate court has not necessarily saved any resources. ${ }^{156}$ Indeed, as the next Section asserts, ${ }^{157}$ the resnltant uncertainty in the interim may impose its own costs, since settlements that would otherwise have been achieved may not occur.

154. A recent study at the federal level set the daily cost to a district court of a civil trial at over $\$ 1,600$ without a jury and over $\$ 2,700$ a day with a jury. Petitioner's Brief on the Merits at $31 \mathrm{n} .16$, Izumi Seimitsu Kogyo Kabushiki Kaisha v. U.S. Philips Corp., 510 U.S. 27 (1993) (No. 92-1123) (citing Budget Dev. Branch, Admin. Office of the United States Courts, Dally Cost of a CIviL TRIAL (February 12, 1992) (on file with the Budget Dev. Branch)).

155. Neary v. Regents of Univ. of Cal., 278 Cal. Rptr. 773, 777 (Ct. App. 1991), rev'd, 834 P.2d 119 (Cal. 1992).

156. See Petitioner's Reply Brief on the Merits at 13, Izumi Seimitsu Kogyo Kabushiki Kaisha v. U.S. Philips Corp., 510 U.S. 27 (1993) (No. 92-1123).

157. See infra Part 11.B.2; see also U.S. Bancorp Mortgage Co. v. Bonner Mall Partnership, 115 S. Ct. 386, 393 (1994) ("The value of additional intra-circuit debate seems to us far outweighed by the benefits that fiow to litigants and the public from the resolution of legal questions."). 


\section{Encouraging Pretrial Settlements in Subsequent Cases}

Given the extent to which our civil justice system relies on settlement, ${ }^{158}$ collateral estoppel probably advances judicial economy more through its ability to stimulate pretrial settlements than its tendency to reduce trial time. Commentators have noted that collateral estoppel, "[a]lthough a rule of judicial procedure, ... makes itself heard primarily outside the courtroom." 159 One way in which it does so is by encouraging parties to settle their differences, without ever going to trial, once a final judgment in another action has been rendered resolving issues which the parties would otherwise have to contest. When settlement is reached before trial, the expenditure of judicial resources is likely to be insubstantial. ${ }^{160}$ As the Neary court recognized, "a postjudgment settlement is perhaps less efficient than a pretrial one."161 Thus, even if, as Neary asserted, allowing stipulated reversal on appeal will encourage appellate settlements, courts may in fact realize a net efficiency gain from denying stipulated reversal to preserve collateral estoppel if estoppel generates even a relatively small increase in incentives to settle before trial.

Litigation theorists have developed a model for analyzing how litigants decide whether to settle or proceed with litigation. ${ }^{162}$ The model analyzes the decision as an investment opportunity ${ }^{163}$ in which the "return" from "investing" in the litigation is compared with the "return" from "investing" in a settlement. Consequently, while myriad factors can influence whether or not parties will reach a settlement, the most important determinant is the extent of difference between the parties' predictions of the ultimate outcome of the litigation adjusted for the net cost of litigation. ${ }^{164}$ If there is a range of dollar amounts ${ }^{165}$ in

158. In fiscal year 1994-95, almost 1.13 million cases were filed in Califomia Superior Courts (which had 789 judges) and almost 7.76 million cases were filed in California Municipal and Justice Courts (which had 670 judges). OFFICE of COURT TECHNOLOgY AND INFormation and Pub. INFormation OfFice, Judicial Council of California/Administrative OfFice of the Courts, Annual Data Reference: 1994-95 Caseload Data by Individual Courts 10, 55 (1995). That translates into an average annual caseload of 6,100 cases per California trial court judge. Obviously, adjudicating of all of them would be impossible. See also Neary, 834 P.2d at 121 (noting that "need for settlements is greater than ever before").

159. Bruce L. Hay, Some Settlement Effects of Preclusion, 1993 U. ILL. L. Rev. 21, 51.

160. This may not be the case with litigants' resources. Pretrial activities may involve substantial party efforts and investment in pleading, discovery, and pretrial motions. See Neary, 834 P.2d at 123; cf. Green, supra note 40, at 183 (noting that "the proportion of judicial to party efforts" is much smaller in the pretrial period than at trial).

161. Neary, 834 P.2d at 121.

162. The formulation of this model is generally attributed jointly to William M. Landcs, An Economic Analysis of the Courts, 14 J.L. \& ECoN. 61, 66-69 (1971), and Richard A. Posner, An Economic Approach to Legal Procedure and Judicial Administration, 2 J. LEGAL STud. 399, 417-29 (1973).

163. See Fisch, supra note 1, at 632.

164. See Richard A. Posner, Economic ANalysis of Law 554-60 (4th ed. 1992); Stephen 
which the defendant's expected loss from litigating exceeds the plaintiff's expected gain, there will exist potential settlement prices at which both the plaintiff and defendant would consider themselves better off compared to their expected litigation outcome. In that case, the parties will settle somewhere within this price range. ${ }^{166}$ Otherwise, they will hitigate. The responsibility of each party for its own litigation $\operatorname{costs}^{167}$ is enough to broaden the opportunities for settlement, since it alone both decreases the plaintiff's expected recovery from litigation and increases the defendant's expected loss from litigation.

Where the facts to be determined or law to be applied by the court are uncertain, the parties' assessments of the case are likely to diverge, yielding a situation in which they will not settle. The availability of a prior judgment to collaterally estop the relitigation of certain issues can lessen the uncertainty facing the parties. ${ }^{168}$ The party to whom the prior finding is adverse will become less optimistic about the likelihood of its own success after litigation, bringing the parties' expected results from litigation closer together. This change in expectation will, in turn, draw the parties' settlement values closer together and facilitate settlement.

The settlement incentives that can be generated by a final judgment can be illustrated by returning to the products liability example involving $\mathrm{P} 1, \mathrm{P} 2$, and $\mathrm{D}$. Assume that the $\mathrm{P} 1$ vs. $\mathrm{D}$ action never occurred and that $\mathrm{P} 2$ has filed suit against $\mathrm{D}$ for strict products liability. If $\mathrm{P} 2$ thinks she has an 80 percent likelihood of winning a $\$ 1$ million judgment with litigation costs of $\$ 200,000$, her expected recovery is $\$ 600,000$. $^{169}$ If $D$, believing it can demonstrate that its product was safe, thinks it has only a 20 percent chance of losing and being held liable for $\$ 1$ million to P2 after expending litigation costs of $\$ 200,000$, its expected loss is

McG. Bundy \& Einer Richard Elhauge, Do Lawyers Improve the Adversary System? A General Theory of Litigation Advice and its Regulation, 79 CALIF. L REv. 313, 365 (1991).

165. For the sake of simplicity, this model treats all cases as though only money damages are involved. It could be adjusted to consider equitable relief, such as injunctions, by simply assigning a dollar value to that relief, see Fisch, supra note 1, at 633 n.221. A judgment that awards an injunction would translate into a gain to the plaintiff, and a loss to the defendant, in that amount.

166. Precisely where the parties will settle within the range is likely to depend on their relative strategic ability and bargaining power. See Note, Exposing the Extortion Gap: An Economic Analysis of the Rules of Collateral Estoppel, 105 HARv. L. REv. 1940, 1945 n.21 (1992).

167. This is known as the "American Rule." YeAzell, supra note 24, at 304. Applicability of the "American Rule" is the usual case, absent a fee-sbifting contractual provision, rule, or statute. See, e.g., FED. R. Civ. P. 11 (sanctions including legal fees); CAL. Civ. Code \$ 1717 (West 1985 \& Supp. 1996) (contractual shifting of fees and costs); CAL. Civ. PRoc. CODE § 1021.5 (West 1980 \& Supp. 1996) (award of fees to "private attomeys general").

168. See Barnett, supra note 1, at 1074 n.224 (arguing that stipulated reversals might increase the uncertainty facing litigants by eliminating collateral estoppel, and thereby reduce the chance of settlement).

169. That is, Expected Recovery $(\mathrm{P} 2)=(80 \% \times \$ 1,000,000)+(20 \% \times \$ 0)-\$ 200,000=$ $\$ 600,000$. 
$\$ 400,000 . .^{170}$ Assuming $\mathrm{P} 2$ and $\mathrm{D}$ are risk neutral, they will choose to litigate, because there are no settlement values at which both $\mathrm{P} 2$ and D would consider themselves better off.

Now, consider the effect of an existing final judgment in P1's favor against $\mathrm{D}$, premised on a finding that D's product is unreasonably dangerous. The judgment injects an element of greater certainty into P2 vs. $\mathrm{D}$ settlement negotiations. Under the doctrine of offensive collateral estoppel, P2 should be able to invoke the judgment in its action against $\mathrm{D}$ to preclude it from relitigating the product's dangerousness. Assume that the prior resolution of the dangerousness issue means that both parties now believe that $\mathrm{P} 2$ has a 95 percent chance of collecting a $\$ 1$ million judgment. Now, P2 and D are likely to settle. P2's expected recovery is now $\$ 750,000^{171}$ and D's expected loss has jumped to $\$ 1.15$ million. ${ }^{172}$ The parties will have an incentive to settle somewhere in the range between $\$ 750,000$ and $\$ 1.15$ million, since both are better off settling (and avoiding litigation costs) anywhere within the range, than litigating.

If P1's judgment against D had fallen victim to a stipulated reversal, the settlement posture of $\mathrm{P} 2$ vs. D would have been as if that action had never occurred. The resultant uncertainty would have prevented settlement in $\mathrm{P} 2$ vs. D, and the parties would have litigated the dangerousness issue again, unnecessarily. If a stipulated reversal request in P1 vs. D were rejected, and the judgment affirmed, settlement between P2 and D would be generated. It appears, then, that the same number of settlements may be generated, whether or not stipulated reversal is granted.

We can expect the efficiency gains to be much greater where stipulated reversal is denied and collateral estoppel preserved. Stipulated reversal terminates only one action, while the potential for collateral estoppel may, in some cases, trigger settlements in multiple cases. For example, it is likely in the products liability example above that there will be more than two injured plaintiffs. A judgment entered against $\mathrm{D}$ in the first action, including a finding that D's product was unreasonably dangerous, will reduce uncertainty about the likely outcome of litigation between D and all remaining plaintiffs. This greater certainty may facilitate settlement negotiations in some or all of the cases in the way that potential collateral estoppel triggered a settlement between $\mathrm{P} 2$ and $\mathrm{D}$ in the above example. Corresponding savings to the judicial system also will be realized.

170. That is, Expected Loss $(D)=(20 \% \times \$ 1,000,000)+(80 \% \times \$ 0)+\$ 200,000=\$ 400,000$.

171. That is, Expected Recovery $(P 2)=(95 \% \times \$ 1,000,000)+(5 \% \times \$ 0)-\$ 200,000=\$ 750,000$.

172. That is, Expected Loss $(D)=(95 \% \times \$ 1,000,000)+(5 \% \times \$ 0)+\$ 200,000=\$ 1,150,000$. 


\section{Nonmutual Collateral Estoppel's Effect on the First Action: More Settlement}

Since the abolition of the mutuality requirement for issue preclusion, many scholars have examined how parties' expectations of future collateral estoppel impact the initial litigation, in which issues are decided for the first time. ${ }^{173}$ As Professor Michael Green has observed, "[t]he possibility of future preclusion is bound to skew the litigation strategy and objectives of the common party."174 The basic idea is that one party (the "common party") will foresee the risk of being burdened later by an unfavorable resolution in the initial litigation. The common party will have more at stake than its opponent: it wishes not only to minimize its liability in the present case, but also to avoid later preclusion which could result from a loss; its opponent, on the other hand, cares only about its own recovery in the instant action and thus generally will not invest special efforts for the sake of the common party's future opponents. ${ }^{175}$ As a result, it is argued, the common party will have an extra incentive to intensify litigation efforts in the initial action, possibly even litigating a suit that would otherwise have been compromised or dropped. ${ }^{176}$ In this way, nonmutual preclusion might be blamed for an inefficient increase in litigation. Given this premise, to the extent that stipulated reversal presents an opportunity for a losing party to insulate itself from issue preclusion, a potential efficiency argument for stipulated reversal could emerge.

However, such an opportunity already exists-pretrial settlement. Pretrial settlement permits a party facing multiple suits to avoid collateral estoppel, just as stipulated reversal does, but without the burden to the court of proceeding to a judgment that will be nullified. "[P]otential preclusive effects of a trial judgment provide a large incentive for litigants to settle before trial."17n It seems reasonable to predict that fear of future nonmutual preclusion will cause a common party to choose early settlement instead of litigation ${ }^{178}$ since the former will save

173. See, e.g., Green, supra note 40 , at $184-186$; Callen \& Kadue, supra note 44 , at 773 \& n.93, 779-80.

174. Green, supra note 40 , at 184 .

175. See Hay, supra note 159 , at $43-44,46$.

176. See James Wm. Moore \& Thomas S. Currier, Mutuality and Conclusiveness of Judgments, 35 TUL. L. REv. 301, 309-10 (1961).

177. Michael W. Loudenslager, Note, Erasing the Law: The Implications of Settlements Conditioned Upon Vacatur or Reversal of Judgments, 50 WASH. \& LEE L. REv. 1229, 1252 (1993) (emphasis added). See also Fisch, supra note 1, at 636-637. Some commentators do not consider this prospect laudable because they argue that this early settlement incentive creates opportunities for the first opponent of the common party to "extort considerably more ... in settlement than [it] could expect to recover at trial ...." Note, supra note 166, at 1944.

178. Unless it perceives its initial opponent as having a weak case, in which case it might prefer to litigate. See Green, supra note 40, at 185; Callen \& Kadue, supra note 44, at 773 n.93. 
it the costs of litigation. In this way, we can perceive how freely available stipulated reversal threatens to encourage common parties facing potential preclusion to "roll the dice"179 and proceed to litigate cases which they would otherwise settle, since they can do so secure in the knowledge that an unfavorable judgment can be stipulated away.

Moreover, even if the absence of an opportunity to erase judgments' collateral estoppel effects stimulates disproportionate investment in the first action, such an investment may not be entirely unfavorable. Heightened motivation in the first action will give the common party "every incentive to present the best case possible"; ;80 later nonmutual use of collateral estoppel will bind the common party to the outcome of an action in which it had a "full and fair opportunity to litigate." Moreover, if the common party puts on its "best case" in the first action, but loses, it is quite likely that incentives for settlement in future cases will be increased, since the expected outcoines become more certain with the prospect of collateral estoppel. ${ }^{181}$ This greater certainty will yield future savings for the courts, measurable in terms of lawsuits never filed.

\section{III}

\section{THE NEARY EXCEPTION AND THE PUBLIC INTEREST IN Collateral EsTOPPEL}

Neary authorizes appellate courts to deny stipulated reversal only when extraordinary circuinstances, such as a "specific, demonstrable, well established, and compelling" public interest, are present; significantly, the court sidestepped the question whether collateral estoppel satisfies this requirement. ${ }^{182}$ In this Part, I answer yes, arguing that the preclusive effects of judgments constitute a sufficiently important public interest to warrant denying stipulated reversal. The judicial discussions of the exception thus far evince a concern for preserving the formal collateral consequences of judgments which logically extend to protecting collateral estoppel. Beyond losses of judicial economy, the use of stipulated reversal to defeat issue preclusion would permit inconsistent judgments and largely benefit wealthy litigants, thereby eroding

179. The behavior of litigants who seek stipulated reversal or vacatur has often bcen likened to “dice rolling." See, e.g., U.S. Bancorp Mortgage Co. v. Bonner Mall Partnership, 115 S. Ct. 386, 393 (1994) ("Some litigants, at least, may think it worthwhile to roll the dice rather than settle in the district court, ... if, but only if, an unfavorable outcome can be washed away by a settlement-related vacatur."); Fisch, supra note 1, at 596 ("[If vacatur is freely available, al litigant may roll the dice, gamble on a favorable judgment and, if unsuccessful at trial, settle the case after judgment and move for vacatur.... [T] [Te litigant will be no worse off than if he or she had avoided a final judgment by entering into a pretrial settlement.").

180. Callen \& Kadue, supra note 44 , at 773.

181. See supra notes $168-172$ and accompanying text.

182. Neary v. Regents of Univ. of Cal., 834 P.2d 119, 125 (Cal. 1992). 
public confidence in the judiciary as a reliable and fair system of dispute resolution. Additionally, permitting stipulated reversal to trump estoppel usurps later courts' prerogative to decide whether prior factual findings should be preclusive and is altogether unnecessary to protect litigants from perceived unfairness in the modern broadened application of collateral estoppel. Consequently, courts of appeal deciding Neary motions should take account of trial court judgments' potential preclusive consequences.

\section{A. Protecting Judgments' Collateral Consequences: The Case Law Thus Far}

Neary and its progeny have not sufficiently refined the extraordinary circumstances exception to the point that one can determine with certainty what circumstances warrant denial of stipulated reversal. But the contours of the evolving doctrine suggest that the public interest in a judgment's likely use as collateral estoppel will, or at least should, be held sufficient to overcome the Neary presumption.

\section{Neary: An Implied "Collateral Estoppel Exception"?}

The Neary court insisted that a trial court judgment is not valuable in itself as "a statement of 'legal truth," "183 as precedent, ${ }^{184}$ or as a "commentary" on the behavior of the parties, ${ }^{185}$ but "expressly reserve[d]"186 the question whether a judgment's potential use for collateral estoppel was of sufficient public interest to warrant denial of a stipulated reversal motion. ${ }^{187}$ Notably, collateral estoppel was the only collateral consequence of a trial court judgment which the Neary majority acknowledged as a potential public interest opposing stipulated reversal, but did not reject as "amorphous and speculative." That the Neary court disposed of only these other asserted public interests suggests that it considered collateral estoppel to be a candidate to satisfy the Neary exception. Moreover, as discussed earlier, cases in which stipulated reversal is sought are likely to be ones in which a party fears the judgment below will be employed against it through collateral estoppel. ${ }^{188}$ Consequently, a court reviewing a stipulated reversal motion will frequently perceive that granting the motion will mean the loss of a judgment that would have affected future litigation; occasionally, outsiders who hope later to invoke the judgment will bring this issue to the

183. Id. at 124.

184. See id.

185. Id. at 126 .

186. Id. at $129 \mathrm{n} .1$ (Kennard, J., dissenting).

187. See id. at 125.

188. See supra Part 1.C.3. 
court's attention. Because of this, collateral estoppel is the concern most likely to arise before appellate courts following Neary's guidance not to "expend significant resources [searching for extraordinary circumstances weighing against reversal] unless a nonparty comes forward and objects ... or unless some problem is apparent in the record." As a result, one observer has concluded that it was a "collateral estoppel exception that the Neary majority allude[d] to." 190 At the very least, the court's discussion probably indicates that the public interest in collateral estoppel raises a difficult issue to analyze in the abstract, and that the court would welcome more concrete presentation of the question in future cases.

Justice Stanley Mosk's Neary concurrence ${ }^{191}$ implies that he believed the requirement that a court of appeal review the circumstances "case-by-case"192 for reasons to deny a stipulated reversal request would involve an investigation into the trial court judgment's collateral estoppel effects. Justice Mosk said that, for example, an appellate court should prevent a "defendant held liable for a product found ... negligently designed or manufactured [from] wip[ing] that judgment out of existence in order to deter other victims from seeking recourse."193 This scenario clearly implicates collateral estoppel, since "wiping that judgment out of existence" would chiefly "deter other victims" by rendering collateral estoppel unavailable, thereby increasing the cost and difficulty of proving their cases against the defendant.

\section{Krug: The Public Interest in Preserving Judgments' Disciplinary Consequences}

The first published California appellate decision to apply the Neary rule was Norman I. Krug Real Estate Investments, Inc. v. Praszker. ${ }^{194}$ Krug invoked the public interest exception to deny in part a stipulated reversal request. The controversy arose between the holder of an unrecorded junior deed of trust and a real estate broker who negotiated a sale of the subject property. The broker failed to inform the deed holder of the pending sale or to disclose the existence of the unrecorded interest to the buyer, resulting in the deed holder's loss of his security interest. The deed holder sued the broker and his real estate agency,

189. Id. at 126.

190. An Online Roundiable: The California Supreme Court at Mid-Decade, ThE ReCorder (S.F.), Winter 1994, at 1, 29 (quoting Paul Fogel, Esq.) (emphasis added).

191. Neary, 834 P.2d at 126-27 (Mosk, J., concurring); see also State ex rel. State Lands Commission v. Superior Court (Lovelace), 900 P.2d 648, 667 (Cal. 1995) (Mosk, J., concurring) (recanting "somewhat equivocal" concurrence in Neary and endorsing Justice Kennard's Neary dissent).

192. Neary, 834 P.2d at 125.

193. Id. at 127 (Mosk, J., concurring).

194. 28 Cal. Rptr. 2d 498 (Ct. App. 1994). 
arguing and prevailing on the theory that the defendant broker's inaction breached a duty of care owed to him. ${ }^{195}$

In the First District Court of Appeal, ${ }^{196}$ the parties reached a settlement requiring a joint motion for stipulated reversal. The court granted the motion as to the judgment against the realty company, but invoked the Neary extraordinary circumstances exception to deny the motion as to the judgment against the broker. ${ }^{197}$ In discussing the ruling, the court of appeal attempted to further refine the scope of the exception by setting out a rule of thumb:

The [extraordinary circumstances] exception ... cannot be defined by formula, though it will more likely be present when the judgment in question involves important public rights, unfair, illegal or corrupt practices, or torts affecting a significant number of persons. Whether stipulated reversal would deprive the public of an important benefit must in every case be determined " from a realistic assessment of all the pertinent circumstances." "198

The parties had represented to the court that no cause for exception to the Neary rule was present. ${ }^{199}$ However, the court's own investigation indicated that the judgment against the defendant broker would provide a basis for disciplinary action against him under California Business and Professions Code section 10177.5. ${ }^{200}$ The court also noted that collateral estoppel would bar the defendant broker, at the disciplinary stage, from relitigating facts established by the judgment below that would

195. See id. at 501 (recounting facts as related in earlier opinion in Norman I. Krug Real Estate Investments, Inc. v. Praszker, 269 Cal. Rptr. 228 (Ct. App. 1990)).

196. Notably, Krug was decided in the same District, and even by the same panel, that heard Neary. In a concurrence, Presiding Justice Kline took this opportunity to present a rebuttal to the California Supreme Court's reversal of his opinion in Neary. See id. at 504-09 (Kline, P.J., concurring) (arguing that "Neary debases the judicial coin with the currency of a false expediency" and that its "presumption is destined to plague the appellate courts of this state").

197. See id. at 499,504 . The court granted the motion as to the realty company because the person who had since come to own and operate it "had nothing to do with the transaction underlying the judgment." Id. at 504.

198. Id. at 501-02 (citation omitted) (quoting California Common Cause v. Duffy, 246 Cal. Rptr. 285, 292 (Ct. App. 1987)).

199. See id. at 501 (quoting defendants' counsel as submitting that "it does not seem possible that the resolution of this dispute by settlement could prejudice third parties and no such interested parties are known to counsel for either broker").

200. See id. at 502. The court apparently discovered this possibility in reviewing its own opinion in an earlier Krug appeal, Norman I. Krug Real Estate Investments, Inc. v. Praszker, $269 \mathrm{Cal}$. Rptr. 228 (Ct. App. I990). Section 10177.5 provides that "When a final judgment is obtained in a civil action against any real estate licensee upon grounds of fraud, misrepresentation, or deceit with reference to any transaction for which a license is required under this division, the commissioner may, after . . . hearings, ... suspend or revoke the license of such real estate licensee." CAL. Bus. \& Prof. Code $\S 10177.5$ (West 1987). The Krug court determined that the judgment below finding the broker had breached a duty was sufficient to trigger section 10177.5 discipline. See Krug, $28 \mathrm{Cal}$. Rptr. 2d at 502. 
also constitute elements of an ethical offense. ${ }^{201}$ Consequently, allowing stipulated reversal would "effectively deprive the [real estate] commissioner of the ability to act pursuant to section 10177.5" and permit "a real estate broker who may have acted unethically to purchase disciplinary immunity from one of the consequences of his impropriety."2012 The court of appeal found this frustration of the state's disciplinary scheme for real estate brokers to be contrary to the public interest. ${ }^{203}$

The effect of the Krug court's decision to deny the motion for stipulated reversal was to prevent the destruction of the trial court judgment's collateral estoppel effects. Under Business and Professions Code section 10177.5 , the judgment, if preserved, would permit the state real estate commissioner to suspend or revoke the broker's license. Section 10177.5 is essentially a collateral estoppel provision, giving preclusive effect in the disciplinary proceeding to civil judgments that establish violations of another disciplinary provision, section 10176. ${ }^{204}$ As the court of appeal noted, "under section 10177.5, "if the elements of fraud have been proved in the civil action, collateral estoppel principles bar the licensee from attempting to relitigate those facts' ... before the commissioner."205 This prevents the need for the disciplinary proceeding to revisit whether the broker has engaged in punishable conduct. ${ }^{206}$ As does common law collateral estoppel, this statutory regime of issue preclusion promotes efficiency. ${ }^{207}$

The Krug court deemed the prospect of stipulated reversal "unconscionable" because it would permit the broker to "purchase disciplinary immunity" from a regulatory scheme designed to protect

201. See Krug, $28 \mathrm{Cal}$. Rptr. $2 \mathrm{~d}$ at 502 (citing California Real Estate Loans, Inc. v. Wallace, 23 Cal. Rptr. 2d 462, 467 (Ct. App. 1993)).

202. Id. at 502-03.

203. The court of appeal also expressed concern that reversal "could well be interpreted as a judicial nullification" of its holding in an earlier appeal, see Norman I. Krug Real Estate Invs., Inc. v. Praszker, 269 Cal. Rptr. 228, 230-32 (Ct. App. 1990), that the broker had violated a professional duty of care. Krug, $28 \mathrm{Cal}$. Rptr. $2 \mathrm{~d}$ at 503.

204. Section 10176 provides for discipline of real estate licensees if found guilty, inter alia, of "[m]aking any substantial misrepresentation [or] ... [a]ny other conduct ... which constitutes fraud or dishonest dealing." CAL. Bus. \& Prof. CODE § 10176 (West 1987).

205. Krug, $28 \mathrm{Cal}$. Rptr. 2d at 502 (quoting California Real Estate Loans, Inc. v. Wallace, $23 \mathrm{Cal}$. Rptr. 2d 462, 467 (Ct. App. 1993)).

206. The Second District Court of Appeal, upholding section I0177.5's constitutionality in Denny v. Watson, 250 P.2d 692 (Cal. Ct. App. 1952), appeal dismissed, 346 U.S. 803 (1953), remarked that "the section commends itself from a practical, common sense viewpoint. It saves duplication of proof .... In this case petitioners had their day in court. They were represented by counsel. The issue of their fraud was heard and determined in that tribunal." Id. at 694.

207. Section 10177.5 also prevents the appearance of inconsistency and manipulation that could result if a civil judgment finding the defendant has engaged in conduct subjecting him to discipline is undermined by an administrative finding that the defendant has done nothing wrong. See infra Part III.B.-C. 
the public. ${ }^{208}$ The unique "public rights" nature of the scheme that the court of appeal sought to protect might lead one to the conclusion that it stretches the court's logic too far to argue by implication that gardenvariety collateral estoppel is to be protected under the Neary exception. Indeed, the court of appeal's suggested rule of thumb for the applicability of the public interest exception ${ }^{209}$ may suggest just that.

However, it seems more likely that the Krug court was trying to express a broader unwillingness to permit litigants' use of stipulated reversal to buy their way out of the collateral consequences of a judgment. The court of appeal dismissed as irrelevant the assertion that it was unlikely that the defendant broker would ever be disciplined, given his advanced age, poor health, and the fact that he was no longer licensed. ${ }^{210}$ The court stated that such "fortuitous" circumstances "in no way diminish[] the policy reasons against court-ordered reversal."211 Thus, the court appears to have been more troubled by the general context in which stipulated reversal was being attempted than the likely future effect it would have on the broker. The First District, conceding that Neary requires courts of appeal to allow parties to treat a judgment as a bargaining chip among themselves, believes that such exchanges cannot be permitted when a judgment would alter a party's relationship with someone who is not part of the bargain. Avoiding attendant consequences of an unfavorable judgment is impermissible. ${ }^{212}$

Moreover, the court of appeal stated that it had adopted a local rule $^{213}$ requiring parties seeking stipulated reversal to present a declaration to the court containing specified facts "which might indicate that reversal of the judgment would be contrary to the public interest."214 Notably, in addition to requiring the parties to indicate whether the Krug rule of thumb is met, ${ }^{215}$ Local Rule 8 also requires the parties to "disclose[] whether the judgment sought to be reversed may have collateral estoppel or other effects in potential future litigation and, if so,

208. Krug, $28 \mathrm{Cal}$. Rptr. 2 d at 502, 503.

209. See id. at 501 (indicating that, although the public interest exception "cannot be defined by formula, ... it will more likely be present when the judgment in question involves important public rights, unfair, illegal or corrupt practices, or torts affecting a significant number of persons").

210. See id. at 503-04.

211. Id. at 504 .

212. That this was the court of appeal's concern is underscored by the First District's analogy to Krug in deciding People v. Barraza, 35 Cal. Rptr. 2d 377 (Ct. App. 1994), in which it rejected a creative attempt to apply Neary to a criminal case to eradicate a judgment that would have been cause for the defendant's deportation from the United States. The court felt it would be "equally unjust" to permit the defendant to negotiate away (with the district attorney) one of the consequences of his offense (deportation by the federal government) as it would have been to allow the Krug broker to purchase disciplinary immunity. Id. at 380.

213. Cal. R. CT., 15T Apr. DisT., Rule 8.

214. Krug, 28 Cal. Rptr. 2d at 504.

215. See Cal. R. CT., 1ST APP. Dist., Rule 8(2). 
whether any third parties who might be prejudiced by stipulated reversal of the judgment have received notice of the motion therefor."216 Thus, it is fairly clear that the First District Court of Appeal considers potential collateral estoppel effects to be a public interest that warrants an exception to the Neary presumption. ${ }^{217}$

\section{Lovelace: The Public Interest in Precedent}

State ex rel. State Lands Commission v. Superior Court (Lovelace) ${ }^{218}$ presented the California Supreme Court with its first opportunity to revisit its ruling in Neary. In Lovelace, the Califoruia Supreme Court denied a joint request by the parties to dismiss the case and depublish the court of appeal's opinion. The court distinguished the parties' request from a motion for stipulated reversal and, alternatively, relied upon Neary's extraordinary circumstances exception. The court's action prompted claims that the court was "retreat[ing] from its sweeping approval of stipulated reversals"219 in Neary and "expand[ing] the public interest exception... giv[ing] courts of appeal the green light to run with it."'220

Lovelace was a title dispute between the state and owners of land along the Sacramento River, regarding ownership of dry land between the river and the landowners' property that had emerged from the riverbed. ${ }^{221}$ The parties agreed that the land had been formed by the slow accumulation, or "accretion," of debris flowing down the river, caused by hydraulic mining during California's Gold Rush era, river dredging, and other human activities. The issue was the construction of the established "artificial accretion" rule: if the accretion was "natural," the landowners owned it by virtue of their title to the adjacent property; if it was "artificial," the state retained ownership, because it holds title to the riverbed. 222

The superior court granted the landowners' motion for summary judgment, ruling that the landowners owned the land because the transport of the debris by the river's natural flow made the accretion "natural."223 The state filed a mandamus petition in the court of ap-

216. Cal. R. CT., IST Apr. Dist., Rule 8(3).

217 Indeed, just before this Comment went to press, the First District ruled that "the potential for collateral estoppel may militate against a stipulated reversal." Fireman's Fund Ins. Cos. v. Quackenbush, 60 Cal.Rptr.2d 732, 737 (Ct. App. 1997).

218. 900 P.2d 648 (Cal. 1995).

219. Id. at 669 (Kennard, J., concurring).

220. Scott Graham, Court Scales Back Stipulated Reversal Rule, THE RECoRdER (S.F.), Sept. 1, 1995, at 2 (quoting Professor Barnett).

221. See Lovelace, 900 P.2d at $650-51$.

222. See id. at 650 .

223. See id. at 652 . 
peal, which the court denied. ${ }^{224}$ After the Supreme Court granted review, the parties reached a settlement and filed a joint motion, relying on Neary, to dismiss and order that the court of appeal opinion "remain unpublished."22s

The court denied that motion " due to the public interest in having the important and continuing legal issues decided." "'226 In its later opinion on the merits, the court deemed it "appropriate to explain the basis for the order."227 The court stated that it had granted review partly in reliance on the Attorney General's representations that resolution of the "artificial accretion" issue would affect the title interests of "thousands of persons owning property" along California waterways. ${ }^{228}$ Since neither the compelling need for the court to decide the issue, nor the likelihood that similar disputes would arise in the future, had disappeared, the court invoked its traditional power to decline to dismiss cases rendered moot by settlement "where the appeal raises issues of continuing public importance." "229

The Lovelace court found that the Neary rule did not apply to an attempt to vacate or depublish an appellate judgment, because Neary had "considered only the factors relevant to whether a stipulated reversal of a trial court judgment should be honored."230 Stipulated reversal (or depublication) of an appellate judgment differs from the procedure sanctioned in Neary, the court wrote, because, when cases have proceeded to appellate decision, "less is gained by the avoidance of further litigation."231 Moreover, more is lost, because it "would effectively eliminate a precedent-setting appellate decision," whereas Neary only eliminated a trial judgment, which cannot create precedent. ${ }^{232}$

However, even if Neary were controlling, the Lovelace court stated that the Neary extraordinary circumstances exception would apply. Because "either the judgment or the stipulation would bind the State,"233 which was representing the public trust ownership of tidelands, ${ }^{234}$ the Lovelace court found a "compelling" public interest in the outcome of the case, sufficient to justify departure from the Neary presumption,

224. See id. at $652-53$.

225. Id. at 653 .

226. Id. at 653 (quoting order of Sept. 22, 1994).

227. Id.

228. Id.

229. Id. at 654 (quoting Lundquist v. Reusser, 875 P.2d 1279, 1283 n.8 (Cal. 1994)).

230. Id. (citing Lucich v. City of Oakland, 23 Cal. Rptr. $2 d$ 450, 453-55 (Ct. App. 1993) (denying similar motion requesting dismissal of an appeal, based on Neary, on the grounds that it was entered after argument and submission of the matter for decision)).

231. Id.

232. Id.; see also supra note 88 and accompanying text.

233. Lovelace, 900 P.2d at 654 .

234. See State v. Superior Court (Lyon), 625 P.2d 239, 241 (Cal. 1981) (reiterating the public trust doctrine). 
since there was "no reason to believe that similar disputes would not arise in other cases."

\section{a. Neary in Retreat?}

After convincingly explaining that Neary's presumption in favor of permitting stipulated reversal of trial court judgments was inapplicable to a joint motion to dismiss and order the court of appeal's opinion to remain unpublished, ${ }^{236}$ the Lovelace court proceeded to advise that, under the extraordinary circumstances exception, it would have denied the parties' request even if Neary were controlling. Given the public interest in resolution of the important legal issue-the application of the "artificial accretion" rule-and the public trust involved, the court stated that reversal would be inappropriate. ${ }^{237}$

As an initial matter, the willingness of the Supreme Court to invoke the Neary exception (even in dicta) the first time it was asked to apply the presumption in favor of granting the parties' request draws into question how "narrow" An explanation of the court's denial of the parties' motion, which had occurred nearly one year before, was not even necessary. ${ }^{239}$ Moreover, discussing the Neary exception was not essential to an explanation of the court's action, which was sufficiently justified by the argument that Neary did not govern such a request. The fact that the court went out of its way to mention that a specific, demonstrable, well established, and compelling public interest was present might well imply that the court is second-guessing its contention in Neary that usually "the public interests ... against a stipulated reversal will likely be indirect and perhaps even illusory."240

This alternative reasoning in Lovelace, offered in response to the parties' reliance on Neary, indicates that the Supreme Court views a judgment's resolution of a particular issue of law that will affect the outcome of other cases as adequate cause to deny litigants' request for stipulated reversal. Even though it is dicta, this can influence our analysis with respect to a judgment's collateral estoppel effects.

235. Lovelace, 900 P.2d at 654 .

236. See id. at 653-54.

237. Id. at 654 .

238. Neary, 834 P.2d at 125.

239. The court stated that "[b]ecause the order did not set out in full our reasoning, and cannot serve as precedent in other cases, we believe it appropriate to explain the basis for the order." Lovelace, 900 P.2d at 653.

240. Neary, 834 P.2d at 125. A week after the California Supreme Court's order issued in Lovelace, attorney John Ford Elsaesser, Jr., in oral argument before the United States Supreme Court in Bonner Mall, characterized the Lovelace order as "back[ing] away" from Neary. Bonner Mall Transcript, supra note 17 , at *53. 


\section{b. The Preclusion-Precedent Analogy}

Lovelace identified the preservation of precedent as a sufficiently important reason for a court to reject a profferred settlement. The similar rationales and effects of precedent and issue preclusion suggest that the preservation of preclusive effects may be just as worthy a reason to deny stipulated reversal.

A common criticism leveled against stipulated reversal and its counterpart, vacatur, is that they destroy the precedential value of trial court judgments. ${ }^{241}$ A precedent is a rule of law which a court applies to a particular set of facts and which, under the doctrine of stare decisis, will be adhered to in subsequent cases of substantially similar facts by that court and others of equal or lower rank in the same jurisdiction. ${ }^{242}$ Like collateral estoppel, precedent is a form of secondary effect on other actions that flows from judgments. Settlement designed to erase precedent was rejected by the California Supreme Court in Neary and later in Lovelace. ${ }^{243}$ Although they operate with less breadth, collateral estoppel effects, by analogy to the Supreme Court's protective treatment of precedent, should be preserved through the exception to the Neary presumption.

The Neary court emphatically rejected the notion that stipulated reversal of trial court judgments would permit the eradication of precedent with the assertion that " [T] rial courts make no binding precedents." "244 The court apparently meant that trial court judgments, unlike those of appellate tribunals, never formally constrain future judicial decisionmaking on questions of law. Although the court did not elaborate further, the implication was that it was not authorizing stipulated reversal of an appellate court's judgment. ${ }^{245}$ Lovelace confirmed that appellate decisions, in part because of their precedential effects, would not be subject to the Neary presumption. ${ }^{246}$ By this logic, trial court judgments should not be subject to stipulated reversal to the extent that they resolve questions of fact likely to arise again in subsequent litigation. Since collateral estoppel is analogous to precedential effect, it should be considered in the court's decision on a motion for stipulated reversal.

241. See, e.g., Barnett, supra note 1, at 1076; Fisch, supra note 1, at 629-30.

242. See BLACK's LAw DictionaRY, supra note 24, at $814,978$.

243. See Lovelace, 900 P.2d at 654; Neary, 834 P.2d at 124.

244. Neary, 834 P.2d at 124 (quoting Fenske v. Bd. of Admin., 163 Cal. Rptr. 182 (1980)). This statement has been labeled a "manifest nonsequitur" by Professor Barnett. Barnett, supra note 1, at 1076.

245. In dissent, Justice Kennard chided the majority for drawing such a distinction. See Neary, 834 P.2d at 128 (Kennard, J., dissenting).

246. See Lovelace, 900 P.2d at 654 . 
Stare decisis has also been analogized to collateral estoppel as a preclusion doctrine. ${ }^{247}$ Both serve to circumscribe the results a court may reach by making the results of prior litigation authoritative. Stare decisis prescribes that a rule of law once applied to a set of facts must be employed again on comparable facts; collateral estoppel requires that a court's resolution of an issue later be deemed conclusive against a party bound by the initial action. And like the system of precedent, collateral estoppel facilitates people's "ordering of extra-judicial relationships" through "plan[ning] . . . conduct outside the judicial forum."248 For example, where either a rule of law is established as precedent or the resolution of an issue is fixed by collateral estoppel, parties will be freer to use their resources "for purposes other than judicial battle" over the matter, and threats of relitigation designed to extract concessions can be more easily disregarded. ${ }^{249}$ In sum, both stare decisis and collateral estoppel constitute an acknowledgment of the principle that, as Justice Brandeis remarked, "in most matters it is more important that the applicable rule . . be settled than that it be settled right."

More fundamentally, precedential and preclusive effects delineate the boundaries of Neary's principle that "courts exist for litigants."251 Neary relied on this proposition to justify its conclusion that "[s]imple fairness requires that the first and most weighty consideration be given to the parties' interests and that they be accommodated."252 But Lovelace explained its refusal to grant the parties' joint motion to dismiss along different lines: granting the motion would have resulted in the loss of a "precedent-establishing appellate decision ... even though there had been one," and it saw "no reason to believe that similar disputes would not arise in other cases."253 The court's focus cannot be reconciled with a policy of ceaseless accommodation of the parties' interests. Rather, it seems more consistent with solicitude for the interests of outsiders and the public. Thus, the court must have recognized that the potential collateral consequences of judgments necessarily place some limits on the extent to which courts should defer to parties' private bargains.

Here, again, an analogy between precedent and collateral estoppel presents itself, for both doctrines dictate that, beyond just "existing for litigants" before them, courts must consider the collateral consequences

247. See FreEdMAN, supra note 57, at 47-50.

248. Callen \& Kadue, supra note 44 , at 763.

249. See id. at 763-64.

250. Burnet v. Coronado Oil \& Gas Co., 285 U.S. 393, 406 (1932) (Brandeis, J., dissenting).

251. Neary v. Regents of Univ. of Cal., 834 P.2d 119, 123 (Cal. 1992).

252. Id. at 122 .

253. State ex rel State Lands Comm'n v. Superior Court (Lovelace), 900 P.2d 648, 654 (Cal. 1995). 
of a judgmeut on absent third parties. The development of precedent, which the Lovelace court deemed sufficiently important to protect, cannot be explained simply as a benefit to the formal parties to an action. Rather, precedent benefits outsiders and society as a whole. ${ }^{254}$ Similarly, when the judicial resolution of factual issues can be used for nonmutual collateral estoppel, the benefits of litigation extend beyond the parties. Thus, if the protection of precedent in Lovelace means that courts cannot accommodate litigants where to do so would eradicate collateral consequences of litigation extending beyond the parties, collateral estoppel should be similarly protected. ${ }^{255}$

\section{B. The Public Interest in Finality and Reliability}

In addition to collateral estoppel's promotion of judicial economy, California courts have recognized its value in "prevent[ing] inconsistent judgments which undermine the integrity of the judicial system."256 Ensuring consistency in separate actions also "promote[s] certainty in legal relations."257 If parties were allowed endless opportunities to relitigate the same issues, justifiable fear of aberrational judgments might arise. This would undermine society's confidence in the ability of courts to arrive at correct results. ${ }^{258}$ Collateral estoppel removes the prospect of inconsistent judgments so that society can have faith in the courts' initial determination of an issue as an authoritative ruling. This promotes reliance on judgments, which is essential to the success of private actors in conforming their conduct to law.

Of course, consistency is not inherently good; ${ }^{259}$ rather, it is desirable because it both maintains public confidence in the courts and fa-

254. See EISENBERG, supra note 78, at 4-7.

255. One might argue that the premise that courts should protect collateral consequences was discredited by the Neary court's willingness to help the veterinarian defendants avoid the harm they perceived that Neary's libel judgment had done to their reputation. See supra note 97 and accompanying text. Reputational harm is arguably another collateral consequence that flows from judgments. However, reputational harm certainly is distinguishable from precedential and preclusive effects because it is not imposed by the judiciary; rather, it is a product of public perceptions of judicial actions.

256. Clemmer v. Hartford lns. Co., 587 P.2d 1098, 1103 (Cal. 1978).

257. United States v. Munsingwear, Inc., 340 U.S. 36, 38 (1950).

258. Or at least reliable ones. Whether judicial findings actually are "correct" in the sense that they accurately represent truth is ultimately unknowable. Our legal system sceks to arrive at the truth only in conjunction with the protection of other ideals, including the rights of individuals; this does not necessarily assist, and may even hinder, its truth-seeking capacity. Thus, the "correctness" of legal results must be measured by the extent to which they can be relied upon by actors outside the courtroom in attempting to comply with the law. See Green, supra note 40, at $216 \mathrm{n} .418$ (discussing reliability as the "best proxy for truth").

259. One commentator has even asserted that "there are cases... in which the inconsistency produced by repetition can be thought benign." John C. McCoid, II, Inconsistent Judgments, 48 WASH. \& LeE L. REv. 487, 488 (1991). Professor McCoid points out that if two decisions are inconsistent, at least regarding issues of fact, one decision must be wrong; consequently, the "evil 
cilitates reliance on judicial action. ${ }^{260}$ In this respect, the importance of replicability of judicial decisions cannot be overstated because, for the most part, private actors rely on lawyers to determine the law and advise them how to act. ${ }^{261}$ If the outcomes of litigation are not replicable, lawyers' advice will necessarily become less reliable, and planning or dispute resolution "in the shadow of the law" will be frustrated. ${ }^{262}$

Stipulated reversal and vacatur clearly endanger consistency and replicability - by permitting multiple opportunities to litigate, they open up possibilities for differing judicial determinations with respect to an issue. A litigant who loses the initial determination of an issue can stipulate the judgment away on appeal and then return in a later case to assert, and possibly prevail upon, the same position that one court has already rejected. The Neary majority, perhaps recognizing this, sought to reassure that stipulated reversal would not lead to a public perception of judgments as unreliable. The court wrote:

The record will reflect that the reversal was pursuant to a settlement and stipulation. There will be no inference that the jury or trial court erred. Whatever conclusions the public wishes to draw from the litigation can still be drawn after the reversal. To remove any possible doubt in a case of a stipulated reversal, the appellate court can explicitly state in its order that the reversal is pursuant to settlement and does not constitute either approval or rejection of the trial court's judgment. ${ }^{263}$

If this disclaimer can be taken at face value, an outsider reading a stipulated reversal order would be entitled to rely on the reversed judgment. After all, the appeal was resolved without casting any doubt on the correctness of the judgment below. Although the judgment would have remained subject to reversal on the merits had settlement not occurred, the burden on appeal would fall on the appellant, and thus the judgment would be presumptively correct. ${ }^{264}$ Thus, the rhetoric of the stipulated reversal invites reliance on the judgment.

However, as we have seen, the reality of stipulated reversal ensures no such consistency. The reversal of the judgment deprives it of preclusive effect, such that future litigation of the same issue is unconstrained by its findings. ${ }^{265}$ Should that relitigation generate a result contrary to the initial decision, inconsistency will result. Although this is not formal

\footnotetext{
does not lie in the inconsistency; it lies in the erroneous decision." Id.

260. See Lucido v. Superior Court, 795 P.2d 1223, 1235 (Cal. 1990) (Mosk, J., dissenting).

261. See EisenberG, supra note 78, at 10.

262. See id. at 11 ; see also generally Robert H. Mnookin \& Lewis Kornhauser, Bargaining in the Shadow of the Law: The Case of Divorce, 88 YALE L.J. 950 (1979) (discussing how formal law affects behavior of private parties in settlement negotiations).

263. Neary v. Regents of Univ. of Cal., 834 P.2d 119, 124 (Cal. 1992).

264. See Denham v. Superior Court, 468 P.2d 193, 197 (Cal. 1970).

265. See supra Part 1.C.
} 
inconsistency-since only the second judgment will have achieved final judgment status-it is effective inconsistency, since the prior decision was never authoritatively rejected on the merits.

\section{The Public Interest in the Legal System's Integrity- The Appearance of Manipulation}

As Part II demonstrates, ${ }^{266}$ allowing stipulated reversal may entail significant costs to future litigants and the judicial system in the form of foregone collateral estoppel consequences. These losses become even more disturbing when it is noted that the net beneficiaries of stipulated reversal, those litigants most likely to employ it and capture its benefits, are the rich. The key to exploiting stipulated reversal is having money: "[o]nly a litigant with substantial funds can afford settlement and [stipulated reversal]. A poor litigant unhappy with a lower court decision is forced to hope his or her appeal will be successful."267

The parties who are fighting to secure the routine availability of stipulated reversal or vacatur are wealthy business interests that engage in frequent litigation. The lobbying opponents to Senate Bill $102,{ }^{268}$ the measure to restrict the Neary presumption, consisted mainly of insurance companies and insurance trade groups, the California Chamber of Commerce, and the California Medical Association. ${ }^{269}$ In Izumi Seimitsu Kogyo Kabushiki Kaisha v. U.S Philips Corp. ${ }^{270}$ a United States Supreme Court vacatur case that preceded Bonner Mall, the Product Liability Council, Inc. submitted an amicus brief for its membership of almost 100 large U.S. manufacturing companies supporting the use of vacatur. ${ }^{271}$ These entities typify the class of "repeat players," litigants who are involved in frequent litigation over similar factual and legal issues, such that their litigation strategy focuses on the overall outcome of a class of cases, rather than the results of any

266. See supra Part II.

267. Fisch, Vanishing Precedent, supra note 139, at 357. Generally, a party must pay for its adversary's support of stipulated reversal or vacatur. Fisch recounts the story of how one successfuI plaintiff's cooperation in vacating an unfavorable trial court judgment was purchased with a settlement premium of $\$ 200,000$ more than the amount of the plaintiff's claim. See id. at 354 . See also Intel Corp. v. Hartford Accident \& Indem. Co., 692 F. Supp. 1171, 1192 n.32 (N.D. Cal. 1988), (describing terms of the Bankers Trust settlement), aff'd in part, rev'd in part, 952 F.2d 1551 (9th Cir. 1991); Bankers Trust Co. v. Hartford Accident \& Indem. Co., 518 F. Supp. 371, vacated, 621 F. Supp. 685 (S.D.N.Y. 1981).

268. See supra notes 11-13 and accompanying text.

269. Unfinished Business (Summary of S. 102 provided by Cal. State Sen. Bill Lockyer) at 4 (on file with the California Law Review).

270. 510 U.S. 27 (1993) (dismissing certiorari as improvidently granted).

271. Brief of The Product Liability Advisory Council, Inc. as Amicus Curiae in Support of Respondents at app., Izumi Seimitsu Kogyo Kabushiki Kaisha v. U.S. Philips Corp., 510 U.S. 27 (1993) (No. 92-1123). 
one lawsuit. ${ }^{272}$ A repeat player can incorporate stipulated reversal into settlements with successful adversaries on appeal, thereby averting the preclusion of factual contentions which have been rejected before. In this way, the repeat player purchases an opportunity either to prevail in later cases $^{273}$ or to settle on more favorable terms than could have been negotiated had a prior judgment existed to resolve the factual issues. ${ }^{274}$

The availability of stipulated reversal to protect repeat players from the collateral estoppel consequences of losing at trial is likely to undermine public confidence in the fairuess of our legal system. ${ }^{275}$ A rule of civil procedure that permits a particular class of litigants to erase preclusive effects via stipulated reversal would only place another weapon in the rich litigant's arsenal ${ }^{276}$ and "reinforce an already too common perception that the quality of justice a litigant can expect is proportional to the financial means at the litigant's disposal."27 Evenhanded application of collateral estoppel, on the other hand, will ensure a more level playing field in California's courts and, consequently, may enhance public confidence in them. Unlike stipulated reversal, which helps only prior losers who can afford it and their fortunate adversaries who win a judgment, collateral estoppel hurts all those who lose in litigation, rich and poor alike.

\section{Usurpation of Later Courts' Role}

A predictable counterargument is that denying stipulated reversal to permit application of collateral estoppel in subsequent cases usurps

272. See Marc Galanter, Why the "Haves" Come Out Ahead: Speculation on the Limits of Legal Change, 9 LAW \& Soc'y REv. 95, 97-114 (1974) (describing litigation advantages of "repeat players"). Many commentators have discussed vacatur's usefulness to repeat players. See, e.g., Howard Slavitt, Selling the Integrity of the System of Precedent: Selective Publication, Depublication, and Vacatur, 30 HaRv. C.R.-C.L. L. Rev. 109, 118-20 (1995); Fisch, Vanishing Precedent, supra note 139 , at $356-358$.

273. See supra Part III.B. (explaining how stipulated reversal permits the rendering of inconsistent judgments).

274. The way in which the collateral estoppel effects of a subsisting judgment's factual findings operate to bring parties' settlement ranges closer together has already been examincd. See supra Part II.B.2. It also follows that, in a case that would have settled anyway, the certainty of result induced by collateral estoppel could shift the settlement price to the common party's detriment as well. Therefore, a common party can use stipulated reversal to save money if it can bargain for reversal in the first action for less money than the preclusion-induced shift in settlement would have cost it in the second action.

275. Barnett, supra note 1, at 1078 (arguing that stipulated reversal erodes publie respeet for the judicial system by sending the message that it is "one more institution where the dollar calls the tune').

276. See Fisch, Vanishing Precedent, supra note 139, at 357-58 (discussing how "the knowledge that if it goes to trial and loses, it can erase the consequences" allows the wealthy defendant to capitalize on the leverage that the cost and delay of litigation provide).

277. Neary v. Regents of Univ. of Cal., 834 P.2d 119, 127-28 (Cal. 1992) (Kennard, J., dissenting). 
the function of the later courts. It is a fundamental characteristic of the doctrine of collateral estoppel that the deciding court (the court resolving an issue for the first time) cannot dictate that its findings be accorded preclusive effect; that decision resides with the court entertaining an action in which a prior judgment is invoked as collateral estoppel. ${ }^{278}$ This principle follows from the premise that the applicability of estoppel cannot be conclusively determined until later litigation is underway. ${ }^{279}$ Supporters of stipulated reversal may argue that deciding courts should express no opinion regarding, and indeed not even consider, the collateral effects of their judgments and that denying a bargained-for reversal to preserve collateral estoppel would constitute just that.

There is a two-fold answer. First, a court's decision as to the disposition of the case does not invade later courts' role; it merely affects the context in which those courts will function. Preserving a judgment from eradication does not mean that future courts must employ it for collateral estoppel; it just permits them to examine the judgment when invoked to see if the proceedings which resolved the issue were sufficiently fair to warrant issue preclusion. Second, even if denying stipulated reversal arguably usurps the prerogative of later courts, allowing stipulated reversal does so to an even greater extent. When stipulated reversal is granted, the lower court judgment never becomes final, wholly removing the prospect of preclusion; ${ }^{280}$ when it is denied, the later court possesses its usual discretion to apply or withhold collateral estoppel. If denying stipulated reversal constitutes the expression of an opinion on whether a judgment deserves preclusive effect, then granting stipulated reversal is an emphatic rejection of preclusion. Ironically, then, usurpation of future courts' function is precisely what those who request stipulated reversal desire: they petition to strip those courts of the opportunity to consider whether (presumptively correct) ${ }^{281}$ prior resolutions of common issues should be accorded collateral estoppel effect. ${ }^{282}$

278. See Restatement (Second) of Judgments § 28 (1982); Fisch, Vanishing Precedent, supra note 139 , at 352.

279. See Fisch, supra note 1, at 617. This is undoubtedly true, because the application of collateral estoppel requires finding first that the issues involved in the first and second suits are identical and then examining whether there are any equitable reasons to deny collateral estoppel (such as different procedural opportunities available to the burdened party or a different standard of proof).

280. See supra notes 104-108 and accompanying text.

281. See Denham v. Superior Court, 468 P.2d 193, 197 (Cal. 1970).

282. A California trial court which accords collateral estoppel effect to a prior judgment reversed by stipulation almost certainly invites reversal on appeal since Bernhard's express requirement of a final judgment on the merits is unmet. See supra notes 29, 104-108 and accompanying text. However, it is not necessarily error for a trial court to decline to apply collateral estoppel to a prior final judgment (presumably, even one preserved by the denial of a stipulated reversal request) even where the threshold requirements are met. Rather, courts have discretion to 


\section{E. Remedy for Unfair Offensive Preclusion?}

One attractive rationale for allowing stipulated reversal to deprive judgments of preclusive effect is based on the premise that collateral estoppel, especially offensive nonmutual estoppel, has inequitably harsh consequences. ${ }^{283}$ Since a party may unfairly be burdened later by an adverse judgment's preclusive effect, the argument goes, it should be allowed to opt out of collateral estoppel by settling the initial case on appeal and obtaining reversal. In this way, stipulated reversal acts as a remedy for the unfairness inherent in the modern expanded form of collateral estoppel. ${ }^{284}$

This argument is flawed, however, to the extent that it overlooks the equitable limits that already have been incorporated into the doctrine of collateral estoppel. ${ }^{285}$ If a party has had a "full and fair opportunity to litigate" an issue, and the court has resolved that issue against the party, it seems fair to deem the matter settled in future actions between the same parties. Even in controversies between the losing party and a third party, the third party has a plausible claim that it should not have to go to the expense of litigating matters that its opponent has already lost. The familiar concern for having one's "day in court," although usually appealed to as a due process protection of the opportunity to be heard, ${ }^{286}$ should also be construed to limit the number of times a litigant must be allowed to contend a certain position. Thus, even in nonmutual contexts, the application of collateral estoppel is generally fair, so long as the prerequisite "full and fair opportunity to litigate" is observed. Even as collateral estoppel has evolved into a more expansive mechanism for precluding relitigation, it has been tempered by limits to ensure that those findings deemed final warrant not only confidence in the process from which they emerged, but also their substantive accuracy.

Collateral estoppel possesses an internal "safety valve" that protects losing parties in such a way that they need not purchase stipulated

"look[] to the public policies underlying the doctrine before concluding that collateral estoppel should be applied in a particular setting." Lucido v. Superior Court, 795 P.2d 1223, 1226 (Cal. 1990).

283. Along these lines, one commentator has argued that vacatur should be denied where the judgment would give rise to defensive collateral estoppel in future cases, but that vacatur should be discretionary in cases where offensive collateral estoppel might result. See Zeller, supra note 139, at 874-878.

284. See Respondents' Brief at 38, Izumi Seimitsu Kogyo Kabushiki Kaisha v. U.S. Philips Corp., 510 U.S. 27 (1993) (No. 92-1123) (arguing vacatur upon settlement "allows courts to protect defendants from substantial inequities that may result from an application of offensive nonmutual collateral estoppel").

285. See Restatement (SECOND) OF JUdGMents $\& 28(1)$ (1982) (inability to have obtained appellate review in initial action); $i d$. $\$ 28(3)$ (differences in procedural opportunities or jurisdiction); id. $\S 28(4)$ (difference in burdens of persuasion); id. $\S 28(5)$ (b) (insufficiently foreseeable at time of initial action that issue would arise again); $i d$. $\S 28(5)(c)$ (inadequate opportunity or incentive to obtain full and fair adjudication in first action).

286. See supra note 33 and accompanying text. 
reversal to get a fair shake. ${ }^{287}$ Where the court considering preclusion adheres to its obligation to examine the circumstances of the prior determination before allowing collateral estoppel, one full and fair opportunity to litigate for the burdened party will be ensured. ${ }^{288}$ As a result of this, the first post-Bernhard commentator to decry the potential harshness of broad nonmutual preclusion ${ }^{289}$ later recanted after observing that the California courts were tempering the doctrine where inconsistent judgments had arisen or where it appeared the precluded party had lacked an adequate incentive to litigate the issue in the initial case. ${ }^{290}$

It is quite likely that, in cases in which stipulated reversal is sought, the judgment at stake will be a strong candidate for the future application of collateral estoppel. As discussed earlier, avoiding collateral estoppel effects is viewed as the prevalent motivation for seeking stipulated reversal. ${ }^{291}$ Thus, a losing party which seeks stipulated reversal can hardly argue that its incentive to invest maximum efforts in the initial litigation was limited by the insufficient foreseeability of the same issues arising in subsequent litigation. ${ }^{292}$ The very course of action taken by that party suggests it "did have a strong incentive to litigate fully, as the impetus for the settlement was the foreseeability of future litigation." 293 For such parties, future litigation with other parties, "far from being speculative, [is] most definitely contemplated." "294 Moreover, a party which can afford to offer its opponent a premium to settle with a stipulation for reversal ${ }^{295}$ likely had the resources to fight its opponent on the merits. The upshot is that stipulated reversal is sought precisely in those cases where we would consider it fair to bind the loser in subsequent litigation.

To the extent that collateral estoppel is flawed, that it unfairly subjects parties to additional litigation costs in the initial litigation or to surprising preclusion later, the remedy is not stipulated reversal. If that were the case, it would seem far wiser to avoid complexity and merely constrain courts in applying collateral estoppel, rather than creating a new procedure (and consequently a new body of law) to assist parties in

287. See Petitioner's Reply Brief on the Merits at 2, 8-12, Izumi Seimitsu Kogyo Kabushiki Kaisha v. U.S. Philips Corp., 510 U.S. 27 (1993) (No. 92-1123) (arguing that "Established Collateral Estoppel Law Already Strikes the Balance Between Finality and Fairness").

288. See Restatement (SECOND) OF Judgments \$ 28 (1982).

289. See Currie, supra note 40 , and accompanying text.

290. See Brainerd Currie, Civil Procedure: The Tempest Brews, 53 CALlF. L. Rev. 25, 27-29

(1965).

291. See supra note 138 and accompanying text.

292. See RESTATEMENT (SECOND) OF JUDGMENTS § 28(5)(b) (1982).

293. Rappaport, supra note 139, at 739.

294. Petitioner's Reply Brief on the Merits at 13, Izumi Seimitsu Kogyo Kabushiki Kaisha v. U.S.

Philips Corp., 510 U.S. 27 (1993) (No. 92-1123).

295. See supra note 266 and accompanying text. 
avoiding it. ${ }^{296}$ Thus far, the courts have not found these flaws significant enough to warrant rolling back collateral estoppel; rather, they have "determined that the economies provided by preclusion outweigh such concerns."297 Perhaps more importantly, a tool to allow a party to shield itself from collateral estoppel's burdens should not require consent of the party's opponent, as does stipulated reversal. Such consent will usually be obtained by offering the opponent a more favorable settlement-more money. This creates an extreme danger that the procedure will become a shield available only to the wealthy. Certainly, if collateral estoppel is unfair, it is not just unfair to those with deep pockets. If stipulated reversal is embraced as the solution for the unfairness of preclusion, it will only create a new fairness problem-one of unequal procedural opportunities between similarly situated parties.

Courts and commentators have identified serious concerns about the incentives and burdens created by offensive nonmutual collateral estoppel. This has resulted in the imposition of a series of restraints on the application of offensive estoppel, designed to ensure that those to be precluded had one adequate opportunity to make their case. But the California courts have never backed away from Bernhard's broad endorsement of nonmutual estoppel. Stipulated reversal presents an opportunity for litigants who fear the burdens of offensive estoppel to protect themselves before the first action is ever concluded. However, to permit its use in that manner would unsettle the balance that courts have struck between fairness and finality and replace it with a scale tilted towards the wealthy.

\section{IV}

SEARCHING FOR EXCEPTIONS: APPLYING NEARY IN THE California Courts of ApPeal

\section{A. Neary and Avoiding Collateral Estoppel in the California Courts of Appeal}

In his analysis of the Neary decision, Professor Barnett warned that California Courts of Appeal would "have to wrestle with" whether the possibility that the trial court judgment could give rise to collateral es-

296. Another snggestion is to expand application of collateral cstoppel to bind nonparties. A proposal to this effect has been formulated by the American Law Institute, see AmericaN LAw INSTITUTE, supra note 33, with the goal of removing the "wait-and-see" incentive given to nonparties who could "benefit from an adjudication adverse to an actual party" but could never be bound by a successful party. Id. at cmt. a. The due process concerns raised by such a proposal are substantial and are beyond the scope of this Comment. See Richard A. Epstein, The Consolidation of Complex Litigation: A Critical Evaluation of the ALI Proposal, I0 J.L. \& COM. 1, 50-61 (1990) (raising due process objections to the ALI proposal).

297. Fisch, supra note 1, at 623. 
toppel in other cases would justify denying a stipulated reversal. ${ }^{298}$ Since the Neary decision, however, no California appellate court has explicitly ruled on this issue. This has not been because, as was asserted in Neary, "[c]ollateral estoppel [was] not an issue"299 in these cases. Rather, with the exception of the First District, ${ }^{300}$ California Courts of Appeal seem to be mechanically applying the Neary presumption and granting stipulated reversal routinely in cases when the parties ask for it. By failing to ever consider the potential preclusive effects of judgments before reversing them to effectuate settlements, California appellate courts are, in effect, deciding the "question that the court ducked" in Neary by ignoring it.

In dispositions published during $1995,{ }^{301}$ the California Courts of Appeal granted stipulated reversal motions $s^{302}$ in seven instances ${ }^{303}$ but

298. See Barnett, supra note 1 , at 1075.

299. Neary, 834 P.2d at 125.

300. See People v. Barraza, 35 Cal. Rptr. $2 d 377$ (Ct. App. 1994); Norman I. Krug Real Estate Invs., Inc. v. Praszker, 28 Cal. Rptr. 2d 498 (Ct. App. 1994).

301. The California Official Reports advance sheet volumes contain each District Court of Appeal's minutes, which report the daily dispositions of cases within each District. I read every entry in the minutes in each of the thirty-five advance sheet volumes published during 1995 . These entries covered dispositions (depending on the District) running from roughly October or November, 1994, to October or November, 1995. However, even research this comprehensive does not allow for accurate determination of the number of stipulated reversals granted since courts frequently fail to report the basis for reversal. See supra note 141 and accompanying text.

302. Granting of stipulated reversals is typically indicated in the minutes by language such as "Pursuant to the parties' stipulation for settlement, the judgment appealed from is reversed and the trial court is directed to dismiss the action with prejudice." Kaiser v. Continental Casualty Co., No. B091694 (Cal. Ct. App. 2d, Oct. 13, 1995) in 33 Cal. Official Reports, Adv. Sheets, Court of Appeal Minutes I9 (Dcc. 7, 1995). This is to be distinguished from stipulated dismissal of an appeal, which is usually indicated as follows: "Upon written stipulation filed by the parties to the appeal, the appeal is dismissed and the remittitur is ordered to issue immediately (Califomia Rules of Court, rule 19(b))." Calfarm Ins. Co. v. Sequoia Ins. Co., No. D021882 (Cal. Ct. App. 4th, Mar. 16, 1995) in 15 Cal. Official Reports, Adv. Sheets, Court of Appeal Minutes 37 (June 1, 1995).

303. See Cutujian v. CB Commercial Real Estate Group, lnc., No. B083411 (Cal. Ct. App. 2d, Oct. 18, 1995) in 33 Cal. Official Reports, Adv. Sheets, Court of Appeal Minutes 24 (Dec. 7, 1995); Kaiser v. Continental Casualty Co., No. B091694 (Cal. Ct. App. 2d, Oct. 13, 1995) in 33 Cal. Official Reports, Adv. Sheets, Court of Appeal Minutes 19 (Dec. 7, 1995); In re Margaret D., No. F023227 (Cal. Ct. App. 5th, Aug. 11, 1995) in 26 Cal. Official Reports, Adv. Sheets, Court of Appeal Minutes 43 (Sept. 26, 1995); Henry v. Monaghan, No. D018303 42 (Cal. Ct. App. 4th, May 3, 1995) in 21 Cal. Official Reports, Adv. Sheets, Court of Appeal Minutes (Aug. 3, 1995); Hopkins v. Cooperman, No. H012645 (Cal. Ct. App. 6th, Mar. 6, 1995) in 12 Cal. Official Reports, Adv. Sheets, Court of Appeal Minutes 47 (May 2, 1995); Bately v. Cox, No. F021890 (Cal. Ct. App. 5th, Jan. 12, 1995) in 7 Cal. Official Reports, Adv. Sheets, Court of Appeal Minutes 54 (Mar. 9, 1995); People v. Yost, No. F022114 (Cal. Ct. App. 5th, Dec. 30, 1994) in 6 Cal. Official Reports, Adv. Sheets, Court of Appeal Minutes 38 (Feb. 28, 1995). One other disposition is also arguably a stipulated reversal of a judgment terminating parental rights and approving an adoption plan. It would be more appropriate, however, to classify the disposition as a ruling on the merits, since the court cited as an additional reason for the reversal that "it appear[ed] to be in the best interests of the minor." See In re Raymar P., No. D022615 (Cal. Ct. App. 4th, Mar. 21, 1995) in 15 Cal. Official Reports, Adv. Sheets, Court of Appeal Minutes 39 (June 1, 1995). 
denied only one such motion. ${ }^{304}$ In at least one of the cases, a trial court judgment which foreseeably could have been invoked by later litigants for collateral estoppel purposes was nullified by the court's grant of a stipulated reversal, suggesting that courts of appeal are not inquiring into the potential collateral estoppel effects of a judgment before granting stipulated reversal.

In Bately v. Cox, the Fifth District Court of Appeal granted reversal "[p]ursuant to the parties" stipulation for settlement"30s of a judgment in which the corporate veil of one defendant was pierced to reach the assets of the other defendants, the shareholders. The suit arose when a disappointed investor (Bately) sued a Kern County, California, oil exploration venture (Bercon, Inc.), after being informed that oil drilling financed by his investment had not generated any favorable results and thus he would not receive any return. Cox and Blize, shareholders of Bercon, were also joined as defendants in the action, which alleged breach of contract and fraud. A Kern County Superior Court jury returned a plaintiff's verdict containing findings of fraud and awarding compensatory and punitive damages totaling in excess of $\$ 600,000$. A subsequent hearing before the trial judge resulted in a finding that Bercon was the "alter ego" of its owners, and thus that Cox and Blize were jointly and severally liable with the corporation for the plaintiffs' damages. Defendants appealed and, after reaching settlement with the plaintiff involving "substantial consideration," petitioned the Fifth District for, and were granted, stipulated reversal. ${ }^{316}$

Attorneys for both parties in Bately confirmed that the appellate court did not independently consider the impact the judgment might have in later litigation involving the defendants. ${ }^{307}$ No outsiders intervened to object to reversal..$^{308}$ Given the factual context of Bately, it appears quite likely that, had the judgment stood, it could have given rise to collateral estoppel in subsequent cases against the defendants. According to Bately's attorney, a number of other individuals had invested funds with Bercon and lost money, some even on the same wells as Bately. ${ }^{309}$ If other investors were to sue the corporation, the court's

304. Arguably, this case was not really a denial of a stipulated reversal motion, since the remedy actually sought was substitution of a conviction of one crime for another. See People v. Barraza, No. A063911 (Cal. Ct. App. 1st, Nov. 16, 1994) in 5 Cal. Official Reports, Adv. Sheets, Court of Appeal Minutes 1 (Feb. 16, 1995); People v. Barraza, 35 Cal. Rptr. 2d 377, 381 (Ct. App. 1994).

305. No. F021890 (Cal. Ct. App. 5th, Jan. 12, 1995) in 7 Cal. Official Reports, Adv. Sheets, Court of Appeal Minutes 54 (Mar. 9, 1995).

306. Telephone Interview with Frederick C. Kumpel, counsel for plaintiff in Bately v. Cox (January 30, 1996) [hereinafter Kumpel Interview].

307. Id.; Telephone Interview with Anthony Leggio, counsel for defendants in Bately v. Cox (January 24, 1996) [hereinafter Leggio Interview].

308. KumpeI Interview, supra note 306; Leggio Interview, supra note 307.

309. Kumpel Interview, supra note 306. 
finding in Bately that Bercon should be treated as the "alter ego" of its owners, Cox and Blize, would likely give rise to the use of offensive collateral estoppel against the defendants in subsequent suits.

The California Supreme Court has articulated two requirements for the application of the "alter ego" doctrine. First, there must be "such unity of interest and ownership that the separate personalities of the corporation and the individual no longer exist," and second, "if the acts are treated as those of the corporation alone, an inequitable result will follow." 310 While the second prong, preventing an inequitable result, might differ from case to case, presumably once the first prong, the identity of corporate and individual personalities, has been litigated once, it would not need to be litigated again, and Cox and Blize could be estopped to deny the requirement is met. Indeed, the defendants' attorney stated in an interview that "without a doubt" the defendants had sought reversal to avert collateral estoppel effects of the fraud and "alter ego" findings encompassed by the trial court judgment. ${ }^{311}$

The example of Bately suggests that courts of appeal are not actively looking for "problem[s] ... apparent in the record"312 that warrant an investigation into whether potential collateral estoppel effects make stipulated reversal inappropriate. Thus, the protection of judgments' preclusive effects rests upon the initiative of third parties coming forward to object to stipulated reversal motions, a subject which the next Section examines.

\section{B. Third Parties: Notice and Incentives}

Even assuming that California courts would treat future collateral estoppel consequences as cause to deny Neary motions, the Neary presumption in favor of stipulated reversal sets up enormous obstacles to third parties' ability to protect themselves. Neary prescribes that, in applying the presumption, an appellate court "need not expend significant resources [considering the propriety of reversal] unless a nonparty

310. Automotriz del Golfo de California v. Resnick, 306 P.2d 1, 3 (Cal. 1957).

311. Leggio Interview, supra note 307. Mr. Leggio also insisted that the trial court judgment "clearly would have been reversed" for error had the appeal proceeded. Parties on appeal that agree the trial court committed reversible error can present the court with a "confession of error" upon which it will reverse. See 9 WITKIN, supra note 108, Appeal § 366. "A reversal under these circumstances is for legal error and is not a stipulated reversal..." Neary, 834 P.2d at 129 (Kennard, J., dissenting). Because the parties in Bately invoked Neary and not the rules governing confession of error, the court clearly granted a stipulated reversal, not a substantive judicial decision or reversal upon confession of error. Regardless of whether the defendants would have ultimately succeeded on the merits, or even whether the plaintiff acknowledged this, the court's blessing of the parties' settlement, without any inquiry into the judgment's correctness, annulled the judgment in Bately.

312. Neary, 834 P.2d at 126. 
comes forward and objects to the settlement for some reason." ${ }^{313}$ The litigants themselves, of course, have no interest in bringing such circumstances to the court's attention. ${ }^{314}$ Reliance on nonlitigants to step forward and object to joint motions for stipulated reversals is misplaced.

In his concurrence in Krug, Justice Kline addressed this danger. $\mathrm{He}$ stated, "Neary overlooks the fact that joint requests for stipulated reversal do not arise in the adversarial context American courts take for granted. They are' by nature collaborative."'31s Consequently, Kline argued, it is unreasonable to expect an interested nonparty to know of the proceeding and object, creating a hazard that courts, uninformed by adversarial presentation, will "cut[] off the rights of unconsidered third parties." 316

Even beyond the hazard that Justice Kline addressed, a presumption to grant stipulated reversal unless outsiders object ignores the risk that such outsiders will not do so even if they do get notice of the motion. This potential is essentially a collective action problem for future litigants who face the loss of nonmutual collateral estoppel benefits of a trial court judgment.

The concept of barriers to "collective action" was pioneered by economist Mancur Olson in his seminal work in the field of interest

313. Id. The Neary court also indicated that a court may inquire into the propriety of stipulated reversal if "some problem is apparent in the record." Id.

314. However, they have a duty to do so in the First District. See CAL. R. CT., 1sT APP. DisT., Rule 8. Most likely, the parties will support their motion for stipulated reversal with a short, conclusory memorandum of points and authorities-the one in Krug was only five sentences long. Norman I. Krug Real Estate Invs., Inc. v. Praszker, 28 Cal. Rptr. 2d 498, 500 (Ct. App. 1994). A model form for a memorandum of points and authorities provided in a popular California treatise addresses extraordinary circumstances by merely citing the Neary holding and stating that "[t]here are no such extraordinary circumstances in the present case warranting an exception to this rule. The stipulated reversal will not adversely affect the public interest." JON B. EISENBERG ET AL., California Practice Guide: Civil Appeals and Writs Form 6:A (1994).

315. Krug, 28 Cal. Rptr. 2d at 505 (Kline, P.J., concurring); see also Barnett, supra note 1, at 1074-1075 ("[Neary] overlooks the fact that requests for stipulated reversal do not arise in adversary proceedings such as American courts take for granted. They are by nature collusive.").

316. Krug, 28 Cal. Rptr. 2d at 505 (Kline, P.J., concurring) (quoting Barnett, supra note I, at 1074-1075). Professor Barnett has asserted that this situation raises due process problems. See, e.g., Barnett, supra note 1, at 1075 . However, courts have never treated the potential nonmutual preclusive benefit of a judgment to a nonparty as a substantive right, the deprivation of which would require due process under the Fifth and Fourteenth Amendments. U.S. CoNST. amend. V; U.S. CoNST. amend. XIV, § I. Rather, nonmutual preclusion has been rationalizcd almost exclusively in terms of its fairness to the party burdened by the judgment. See Parklane Hosiery v. Shore, 439 U.S. 322, 332 (1979); Bernhard v. Bank of Am. Nat'l Trust \& Sav. Ass'n, 122 P.2d 892, 895 (Cal. 1942). Indeed, third parties for whom stipulated reversal will mean the loss of nonmutual collateral estoppel benefits have even fared poorly in demonstrating interests in the "property or transaction which is the subject of the action," FED. R. Civ. P. 24(a)(2), sufficient to justify intervention as of right in federal court. See Purcell v. BankAtlantic Fin. Corp., 85 F.3d 1508, 1512-13 (11th Cir. 1996); U.S. Philips Corp. v. Windmere Corp., 971 F.2d 728, 730-31 (Fed. Cir. 1992), cert. granted sub nom. Izumi Seimitsu Kogyo Kabushiki Kaisha v. U.S. Philips Corp., 507 U.S. 907, and cert. dismissed, 510 U.S. 27 (1993). But see National Union Fire Ins. Co. v. Seafirst Corp., 891 F.2d 762, 764 (9th Cir. 1989). 
group theory, The Logic of Collective Action ${ }^{317}$ Olson posited that certain goods, defined as "public" or "collective" goods, are such that the provision of the goods benefits an entire group rather than an individual. This occurs because group members cannot be excluded from consuming the good and there is no need to do so, since consumption of the good by one individual does not inhibit another's consumption. ${ }^{318}$ Examples of collective goods are national defense (a collective good to a nation, a group of people) and protective tariffs (a collective good to an industry, a group of firms). ${ }^{319}$ The free-rider problem that arises from the nature of these goods is that group members often lack adequate incentives, absent some form of compulsion or sanction, to independently invest in resources to support provision of such goods. ${ }^{320}$

Stipulated reversal and eradication of collateral estoppel effects fit well within Olson's "collective action" framework. If parties can routinely employ stipulated reversal to prevent lower court judgments from having preclusive consequences unless outsiders persuade the court to deny reversal, then judgments' collateral estoppel effects take on the character of collective goods. ${ }^{321}$ Those outsiders who could benefit in future litigation by preventing relitigation of an issue resolved in the first action compose a group with an interest in the protection of the judgment. ${ }^{322}$ This group could, of course, upon hearing that a favorable judgment was in jeopardy of stipulated reversal, band together and oppose the parties' motion.

Olson's analysis suggests, however, that such group opposition is unlikely to happen in many cases. In the wake of the burial of the mutuality requirement, an incentive to free-ride exists, since collateral estoppel benefits of a judgment are public goods available to anyone. ${ }^{323}$ Potential future litigants have no incentive to take unilateral action to preserve a judgment; they can use it whether or not they pay for it, as

317. Mancur Olson, The Logic of Collective action (2d ed. 1971).

318. Id. at $14-15 \&$ n.21.

319. Id. at $15 \mathrm{n} .22$.

320. Id. at 15-16. This occurs because a group member's contribution "will not have a noticeable effect" on the ability of the group to provide the public good, and the group member "can enjoy any improvements brought about by others" whether or not he or she has contributed (that is, the member can free-ride). Id. at 16.

321. At least one commentator has described the nonmutual collateral estoppel effects of judgments as public goods and employed Olson's free-rider concept to analyze the insufficient incentives that group members face to invest in producing judgments. See Hay, supra note 159, at 4850. It is reasonable to expect that these insufficient incentives to invest in producing judgments may carry over to the situation of protecting those judgments.

322. For example, returning to my products liability hypothetical, see supra notes $152-53,169$. 172 and accompanying text, if in the first action, P1 was successful in establishing that D's product was unreasonably dangerous, the pertinent group of outsiders would be $\mathrm{P} 2$ and other consumers also claiming injury from the product.

323. See Hay, supra note 159 , at $48-50$. 
long as someone else pays. Many collateral estoppel beneficiaries who know of a pending motion for stipulated reversal will plan to free-ride on the efforts of others. Unfortunately, unless someone takes the initiative to protect the judgment independently, the judgment will fall to stipulated reversal. Sometimes no one in the group will object to stipulated reversal because it does not seem individually rational to do so. An individual will be willing to invest in opposition only if the expected benefits to her exceed her costs. Objection will entail substantial litigation efforts to prove to the court of appeal that the objector meets intervention requirements and is eligible to use the judgment as collateral estoppel in another action, and that consequently stipulated reversal is inappropriate. The expected benefits of objection (the avoided costs of relitigating the issue later) must be discounted by the probability that objection will be unsuccessful. In sum, whenever each potential beneficiary of collateral estoppel foresees costs of intervention that exceed the expected benefits, no one will object to stipulated reversal, and the entire group will lose out on the benefits of preclusion. ${ }^{324}$

Moreover, none of this will matter if potential beneficiaries of a judgment's collateral estoppel effects are never informed that the judgment is in jeopardy. The difficulty of anyone becoming informed of a stipulated reversal motion is epitomized by a recent stipulated reversal granted by Division Five of the Second District California Court of Appeal. In Kaiser v. Continental Casualty Co. ${ }^{325}$ according to the defendants' attorney, the parties filed a stipulated reversal motion and informed the appellate panel of their desire to terminate litigation immediately. That very day, the presiding justice granted the motion, issued remittitur, and telephoned the trial court to direct it to dismiss the complaint. ${ }^{326}$ Stipulated reversal may not always be available on a "same day" basis as it was in the Kaiser case, but we can expect that litigants' and courts' desire for swift resolution will mean that many interested outsiders may never learn that a favorable judgment is in

324. In some cases, it may be economically feasible for a lone potential beneficiary of collatcral estoppel to intervene to try to preserve a judgment, bccause it would cost less to do so than to latcr litigate the common issue at trial. A group of preclusion beneficiaries of which this person is a member will not face serious collective action problems and exemplifies what Olson calls a "privileged" group. See OLson, supra note 317 , at $49-50$ \& n.70. Given that a solitary opponent to the parties' joint motion to reverse will face substantial difficulties in establishing a "compelling ... public interest" against stipulated reversal, the expected benefits of such an effort will be greatly discounted for the improbability of success. This makes it unlikely that many "privileged" groups exist in this context.

325. No. B091694 (Cal. Ct. App. 2d, Oct. 13, 1995) in 33 Cal. Official Reports, Adv. Sheets, Court of Appeal Minutes 19 (Dec. 7, 1995).

326. Telephone Interview with Robert F. Keehn, counsel for defendant Continental Casualty Co. in Kaiser v. Continental Casualty Co. (February 9, 1996). The parties wished to quickly settle their differences to get speedy compensation to the plaintiff, a terminal cancer patient. Id. 
jeopardy ${ }^{327}$ At this stage, the very information that a potentially beneficial judgment faces nullification becomes itself a public good, with attendant problems of group organization and cooperation.

Faced with the phenomenon of the collective action problem, the reader may wonder: "Why should we care? If outsiders have inadequate incentives to follow relevant cases in the courts and intervene to protect beneficial judgments, it's obviously not very valuable to them, and there is no need for paternalism by the courts to disturb that outcome." The answer is that we should be equally solicitous of the interests of unprotected third parties as we are of the litigants themselves. In the collateral estoppel context, the courts often concern themselves with the incentives of litigants burdened by preclusive effects. The expansion of the doctrine of collateral estoppel has been checked by the notion that it is unfair to burden a party with the result of a prior proceeding if that party lacked a "full and fair opportunity to litigate," including an "adequate incentive" to do so. ${ }^{328}$ Indeed, the California Supreme Court, in Teitelbaum Furs, Inc. v. Dominion Insurance Co. ${ }^{329}$ expressly conditioned the availability of nonmutual preclusion on the court's finding, from an examination of the circumstances of the prior case, that the burdened party had "every motive to make as vigorous and effective a defense as possible." ${ }^{330}$ Apparently, protecting a party from preclusion is important enough to warrant judicial inquiry into the party's incentive to protect itself; safeguarding another outsider's interest in preclusion, even where it lacks an incentive to do so for itself, would seem a similarly worthy cause for the courts. As Judge Easterbrook has written, "Judges must have at heart the interests of other litigants in future cases, and hold them equal in weight with the interests of today's." 331

327. See Fisch, supra note 1, at 621 n.165 (citing National Union Fire Ins. Co. v. Seafirst Corp., 891 F.2d 762 (9th Cir. 1989)). National Union is an example of a case in which the third parties did learn of a pending attempt to get vacatur and intervened to defeat it. In related actions, the intervenors were able to use the preserved National Union judgment for issue preclusion. See Davis, Wright \& Jones v. National Union Fire Ins. Co., 709 F. Supp. 196 (W.D. Wash. 1989), aff'd 897 F.2d 1021 (9th Cir. 1990); National Union Fire Ins. Co. v. Davis, Wright, Todd, Reise \& Jones, 551 N.Y.S.2d 774 (App. Div. I990).

328. See Restatement (Second) of Judgments § 29 (1982) (permitting nonmutual collateral estoppel against a party to a judgment "unless [it] lacked full and fair opportunity to litigate the issue in the first action"); id. $\S 28(5)(b)$-(c) (preventing collateral estoppel where relitigation of an issue was "not sufficiently foreseeable at the time of the initial action" or where party "did not have an adequate opportunity or incentive to obtain a full and fair adjudication in the initial action"); Parklane, 439 U.S. at 332 (suggesting preclusion should not be allowed if the party lacked "every incentive to litigate the [prior action] fully and vigorously").

329. 375 P.2d 439, 441 (Cal. 1962).

330. Id.

33I. In re Memorial Hosp., 862 F.2d 1299, 1303 (7th Cir. 1988). 


\section{A Solution?}

As a first step, the California Supreme Court should answer in the affirmative the question addressed by this Comment: do the potential collateral estoppel effects of a judgment constitute cause to deny stipulated reversals after Neary? While that action would represent a significant step for the court, it would still leave unanswered perhaps more daunting questions of how to implement the principle. Specific guidelines for courts ruling upon stipulated reversal motions will be needed.

An essential characteristic of collateral estoppel is that a court rendering a judgment, or ruling on a stipulated reversal motion, cannot be certain whether identical issues will arise in subsequent disputes. Even if the court knows they will, it cannot be certain that collateral estoppel will be permitted. ${ }^{332}$ Thus, if a California appellate court ruling on a stipulated reversal motion considers the issue of collateral estoppel, it will operate under a considerable amount of uncertainty. The court may choose not to worry about this uncertainty. To do so would not be unprecedented, since some federal circuits had taken this very stance with respect to vacatur before Bonner Mall. ${ }^{333}$ Moreover, courts have long been required to consider and protect third party interests that are not easily identifiable, such as in approving settlement of class actions, ${ }^{334}$ and have even invoked their discretion to do so in deciding whether to grant dismissal upon settlement. ${ }^{335}$ Given the uncertainty of preclusion compared to the certainty of the settlement which the parties proffer, however, the natural inclination of busy judges may be to choose the "bird in hand" over "two in the bush" and grant stipulated reversal. This would be a mistake.

332. This is because often "future litigants who might benefit from preclusion are not involved when the court rules on a motion to vacate." David M. Staker, Comment, The Use of Lower Court Judgments as Bargaining Chips: Should Courts Routinely Grant Vacatur When Parties Setlle Pending Appeal?, 43 U. KaN. L. Rev. 233, 252 n.153 (1994). Cases such as National Union, see supra note 327 , in which the future litigant who can benefit from nonmutual collateral estoppel intervenes to oppose a stipulated reversal motion, present a court with more complete representation of the interests at stake, but are bound to arise much less often than unopposed "collusive" joint motions. See supra note 315 and accompanying text.

333. See National Union, 891 F.2d at 769 "'Given the ... possible, although uncertain status of any preclusive effect,... National Union should not be able to avoid those effects through settlement...."); In re Memorial Hosp., 862 F.2d at 1302 ("To the extent an opinion permits the invocation of Parklane, it may have great value to strangers-a value that one or another party to today's case may try to appropriate in the settlement, but which is not theirs to sell." (emphasis added)).

334. See Anstaett, supra note 58, at 104; see also FED. R. Civ. P. 23(e).

335. See State ex rel State Lands Comm'n v. Superior Court (Lovelace), 900 P.2d. 648, 654 (Cal. 1995) (discussing "well-established line of judicial authority recognizing ... [court discretion] to decline to dismiss a case rendered moot by stipulation of the parties where the appeal raises issues of continuing public importance") (citing Lundquist v. Reusser, 875 P.2d 1279, 1283 n.8 (Cal. 1994)); 9 WITKIN, supra note 108, Appeal § 506 (same doctrine). 
Some have argued that the benefits of future estoppel in preventing relitigation are too "speculative"s336 to warrant the sacrifice of the parties' settlement. They have largely pressed their case in unconvincing ways, however. One commentator has concluded that the "fear of relitigation ... appears to be unfounded"337 based on the results of a simple LEXIS search for the party names and issues from ten federal court of appeals cases in which vacatur of a judgment was granted. Finding that "none of the issues ha[d] been the subject of a subsequent reported decision," encouraged by vacatur." rors embodied in this commentator's "test," 340 focusing solely on reported decisions is a poor proxy (even if the only practicable one) for determining whether issues have been relitigated, since reported cases constitute but a small fraction of decided appellate cases, ${ }^{341}$ and an even smaller fraction of decided trial court cases. ${ }^{342}$ Moreover, actual relitigation should not be the test of collateral estoppel's effectiveness; as indicated earlier, the most significant benefits that can be expected of collateral estoppel come from its effect of facilitating the pretrial settlement process. ${ }^{343}$ This suggests that the gains may also be largely invisible, since information on the issues in controversy in settled disputes (which comprise the bulk of the legal disputes in this country) is not readily accessible.

In addition, it is disingenuous for those seeking stipulated reversal to assert that the prospect of resolved issues arising again is merely speculative. Their action, in seeking a settlement that eradicates the risk of future preclusion if such issues should again arise, is clearly predicated upon a recognition that the same controversies could recur with

336. Neary warned that the discovery of a "speculative" interest supporting denial of stipulated reversal would be insufficient to justify a departure from the presumption in its favor. Neary, 834 P.2d at 125.

337. Klingeman, supra note 1 , at 250.

338. Id. at 249 n.111.

339. Id. at $249-50$.

340. To cite just one error, the author "conducted a [LEXIS] search of the 'Courts' file in the 'Genfed' library", id. at $249 \mathrm{n} .111$, indicating that subsequent state court cases were totally ignored; although the ten selected cases were all from federal courts, there is no reason to believe, especially given the possibility of concurrent jurisdiction over federal questions, that issues which arose once in federal courts could not find their way into state courts.

341. At the federal circuit court level, see Elizabeth M. Horton, Comment, Selective Publication and the Authority of Precedent in the United States Courts of Appeals, 42 UCLA L. REv. 1691, 1695 \& n.14, 1696 \& n.15 (1995) (citing L. Ralph Mecham, Administrative Office of the United States Courts, United States Courts: Selected Reports, Table S-3 at 40 (1993)). Many state appellate courts also selectively publish. See, e.g., CAL. R. CT. 976 (prescribing standards for publication of California Court of Appeal opinions).

342. Decisions by trial court judges are only published in significant numbers in the federal system.

343. See supra Part II.B.2. 
other parties. ${ }^{344}$ Otherwise, why would they settle a case (presumably giving up something to get their opponent's consent to reversal) in this way? They cannot have it both ways: either the prospects of repeat disputes over the same issues are significant, in which case collateral estoppel could have a considerable impact, or they are speculative, in which case purchasing a stipulated reversal would be an unwise investment.

The problem, then, does not admit of easy answers. The recognition of potential collateral estoppel effects as a sufficient reason to deny stipulated reversal, if applied so broadly as to prevent stipulated reversal whenever such a potential exists, might threaten to swallow Neary's presumption in favor of the device. That is why it is essential for the California Supreme Court to do what it declined to do in Neary-address the effect of stipulated reversal on judgments' collateral estoppel effects directly and instruct the courts of appeal in how to determine those effects and balance them against the parties' desire for reversal in concrete cases.

A variation on vetoed California Senate Bill 102, which would have required courts to deny stipulated reversal if there is a "reasonable possibility that the interests of nonparties or the public will be adversely affected," ${ }^{345}$ could prove workable. The standard should provide that stipulated reversal be denied, under the extraordinary circumstances exception, when there exists a reasonable possibility that third parties will be adversely affected by the eradication of the judgment's collateral estoppel effects. The flexible threshold of whether there is a "reasonable possibility" that third parties will be harmed takes account of the reality that, in some cases, a court will be able to conclude that it is so unlikely that a judgment will have preclusive effects that are valuable to outsiders that Neary requires that stipulated reversal be granted. ${ }^{346}$ At the opposite extreme, requiring only a "reasonable possibility" also makes clear that the court can deny stipulated reversal without concrete proof that others stand ready to rely on the judgment as collateral estoppel. Moreover, by generalizing the inquiry to whether nonparties are injured by the eradication of preclusive effects, rather than focusing solely on the probability that identical factual issues actually will be relitigated, the proposed standard recognizes collateral estoppel's important role in keeping future controversies out of court through encouraging settlement. ${ }^{347}$

344. See supra notes $290-294$ and accompanying text.

345. Cal. S. 102, Cal. 1993-94 Reg. Sess.

346. This is exactly what the Neary court concluded on the facts of that case, although the conclusion has been criticized. See supra notes $97-98$ and accompanying text.

347. See supra Part ll.B.2. 
Until the California Supreme Court provides guidelines, the courts of appeal should follow the example of the First District Court of Appeal, the main arena for stipulated reversal disputes over the past five years. The First District's Local Rule $8^{348}$ ensures that, in ruling on a stipulated reversal motion, the court will receive more complete disclosure of "facts which might indicate that reversal of the judgment would be contrary to the public interest." ${ }^{349}$ Although this Rule arguably conflicts with the instructions in Neary, ${ }^{350}$ it is not unduly burdensome on the parties and provides valuable information that the court needs if it is to protect the "public interest." There will not always be a prior appellate opinion, as there was in Krug, ${ }^{351}$ to tip the court off to the potential effects of its decision, and, as we have seen, the parties have no incentive to advise the court why it might not want to grant their request. Given the inquisitorial nature of the stipulated reversal proceeding and the importance of the unrepresented interests at stake, the Rule's minimal burden on the parties seems justified.

Moreover, the courts of appeal should also follow the lead of the federal courts by getting the trial court that rendered the original judgment to participate in considering a stipulated reversal motion. In Bonner Mall, the United States Supreme Court authorized federal courts of appeals faced with vacatur motions to "remand the case with instructions that the district court consider the request."352 Remand to the trial court for decision may be fruitless given that "trial court support for stipulated reversal is ... unlikely, [because] ... it is their [sic] independence that is most directly compromised."353 However, requesting the trial court to apprise the court of appeal of the interests relevant to stipulated reversal makes sense, ${ }^{354}$ since the court that rendered judgment in the matter should be more familiar with the facts

348. Cal. R. Cr., 1St App. Dist., Rule 8.

349. Norman I. Krug Real Estate Invs., Inc. v. Praszker, 28 Cal. Rptr. 2d 498, 504 (Ct. App. 1994); see supra notes 212-215.

350. Neary, 834 P.2d at I26 (deeming it "unnecessary" for the parties to present and the court to consider "memoranda of points and authorities and supporting declarations and documentary evidence" proving that "no countervailing factors are present").

351. See supra note 199.

352. U.S. Bancorp Mortgage Co. v. Bonner Mall Partnership, 1 I5 S. Ct. 386, 393 (1994). For examples of cases in which remand has occurred, see American Pub. Communications Council $v$. Alnet Communication Services, Inc., No. 94-7003, 1997 WL 761952, at *1 (D.C. Cir. Dec. 30, 1996); Mancinelli v. IBM Corp., 95 F.3d 799 (9th Cir. 1996); Coles v. Dist. of Columbia, No. 94-7241, 1995 WL 686337, at *1 (D.C. Cir. Oct. 10, 1995); Whitney Benefits, Inc. v. United States, 57 F.3d 1083 (Fed. Cir. 1995).

353. Krug, $28 \mathrm{Cal}$. Rptr. 2d at 508 (Kline, P.J., concurring).

354. Justice Kline solicited such trial court advice in his Krug concurrence: "California trial judges should ... [not be reluctant] ... to advise us of information that may not have been called to our attention by the parties that may warrant reconsideration of an order granting stipulated reversal ...." Id. at 509 n.5 (Kline, P.J., concurring). 
of the case. It may, indeed, present the court of appeal with a situation more akin to the adversarial presentation to which it is accustomed.

These two suggestions should provide the courts of appeal with more information than they would otherwise receive in ruling on stipulated reversal motions and consequently should assist them in determining if the judgment at issue could give rise to later preclusion. Currently, they lack firm guidance as to what weight, if any, to give to the potential for preclusion in determining whether to grant the parties' stipulation. In the end, the California Supreme Court must elaborate upon Neary to assist them in striking the balance.

\section{CoNCLUSION}

In Bernhard v. Bank of America National Trust \& Savings Association, ${ }^{355}$ the California Supreme Court ushered in the postmutuality era, dramatically expanding the doctrine of collateral estoppel, with the recognition that the doctrine is "based upon the sound public policy of limiting litigation by preventing a party who has had one fair trial on an issue from again drawing it into controversy."356 Fifty years later, though that policy remains just as sound, the court issued another opinion, Neary, ${ }^{357}$ that threatens to make Bernhard's "triumph of judicial statesmanship"358 a dead letter. In vesting parties with the power to bargain for stipulated reversal of judgments, Neary arguably hands over the application of nonmutual collateral estoppel to litigants to decide whether they will or will not be precluded from relitigating matters. However, collateral estoppel should not yield to stipulated reversal. Estoppel's beneficial contributions to efficiency and judicial economy are significant enough, and the public's interest in its effectiveness "compelling"359 enough, to justify departure from Neary's "strong presumption in favor of allowing stipulated reversals." ${ }^{360}$ For the California Supreme Court to recognize as much would demonstrate that, half a century after Bernhard, "judicial statesmen" (and stateswomen) still occupy the bench of the court.

355. 122 P.2d 892 (Cal. 1942).

356. Id. at 894 .

357. 834 P.2d 119 (Cal. 1992).

358. Currie, supra note 40 , at 285.

359. Neary, 834 P.2d at 125.

360. Id. 